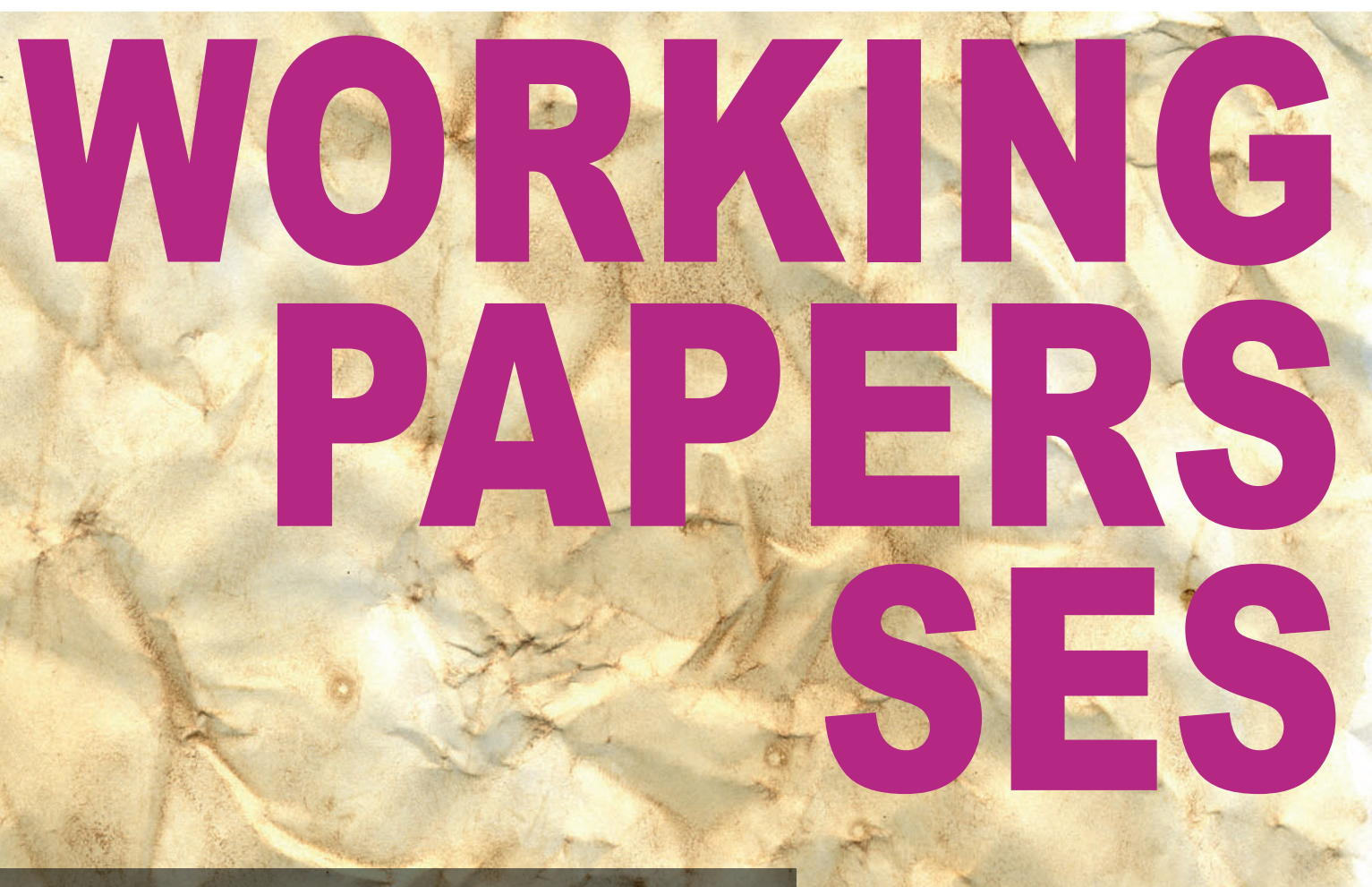

What if dividends were tax-exempt?

Evidence from a natural experiment

Dušan Isakov, Christophe Pérignon, and Jean-Philippe Weisskopf 


\title{
What if dividends were tax-exempt? \\ Evidence from a natural experiment
}

\author{
Dušan Isakov* \\ Christophe Pérignon $\dagger$ \\ Jean-Philippe Weisskopf
}

November 17, 2018

\begin{abstract}
We study the effect of dividend taxes on the payout and investment policy of listed firms and discuss their implications for agency problems. To do so, we exploit a unique setting in Switzerland where some, but not all, firms were suddenly able to pay tax-exempted dividends to their shareholders following the corporate tax reform of 2011. Using a difference-indifferences specification, we show that treated firms increased their payout much more than control firms after the tax cut. Differently, treated firms did not concurrently or subsequently increase investment. We show that the tax-inelasticity of investment was due to a significant drop in retained earnings - as the rise in dividends was not compensated by an equally-sized reduction in share repurchases. Furthermore, treated firms did not raise more equity and/or did not reduce their cash holdings to compensate for the contraction in retained earnings. Finally, we show that an unintended consequence of cutting dividend taxes is to mitigate the agency problems that arise between insiders and minority shareholders.
\end{abstract}

JEL Classification: G35, G38, H25, K34

Keywords: corporate taxes, dividends, payouts, investment, agency problems

\footnotetext{
* University of Fribourg, Boulevard de Pérolles 90, CH-1700 Fribourg, Switzerland. Email: dusan.isakov@unifr.ch

${ }^{\dagger}$ HEC Paris, 1 Rue de la Libération, 78350 Jouy-en-Josas, France. Email: perignon@hec.fr

¥ Ecole hôtelière de Lausanne, HES-SO / University of Applied Sciences Western Switzerland, Route de

Cojonnex 18, CH-1000 Lausanne, Switzerland. Email: jean-philippe.weisskopf@ehl.ch
} 


\section{INTRODUCTION}

Does changing corporate taxes materially affect firms' behavior? Amid conflicting theories, mixed empirical conclusions, and lavish promises made by politicians, the value of the taxelasticity of payout and investment remains unknown in most contexts. In this paper, we study the effect of abruptly removing the dividend tax for some, but not all, firms by exploiting a fiscal shock that occurred in Switzerland in 2011. Using a difference-in-differences specification, we compare the payout and investment policy of firms being affected by the reform with those of firms that are not. The quasi-experimental nature of this fiscal reform offers a unique setup to test whether the tax cut causally affects firms' financial decisions.

The empirical evidence on the effect of dividend tax cuts on firms' payout policy is mixed. Poterba (2004) reports a strong positive long-run (but no short-run) elasticity of dividends with respect to the tax burden on dividends. Chetty and Saez (2005) show that the enactment of the Jobs and Growth Tax Relief Reconciliation Act of 2003 significantly led publicly traded corporations to increase their dividends right after the tax cut. However, Brown, Liang and Weisbenner (2007) show that share repurchases went down at the same time, which left total payout unaffected by the tax cut. Differently, Hubbard and Michaely (1997) show that investors seem to ignore taxation when pricing a stock paying a cash dividend (heavily taxed) and a clone stock paying a stock dividend (lightly taxed). Furthermore, Brav, Graham, Harvey and Michaely (2008) indicate that more than two-thirds of US executives stated that the 2003 dividend tax reduction would definitely or probably not affect their dividend decisions. Recently, Jacob and Michaely (2017) show that conflicting objectives between owners and managers dampen the sensitivity of payout policy to dividend taxation.

The question of the effect of dividend taxes on investment also remains unsettled. Using data on dividends and capital gain taxes from 25 countries, Becker, Jacob and Jacob (2013) find that, after dividend tax cuts, firms with limited internal equity increase their investment relative to firms with plenty of internal equity. On the other hand, Yagan (2015) finds that the 2003 US dividend tax cut had no impact on firms' investment over the subsequent five years. Evidence from Sweden provided by Alstadsæter, Jacob and Michaely (2017) lie between these two views: they show that aggregate dividends did not increase following the local tax cut of 2006 but that cash-constrained firms did increase external equity and investment more relative to cash-rich firms. 
We believe we are in an ideal position to contribute to this important debate. Indeed, the Swiss tax reform studied in this paper has several desirable characteristics that allow us to avoid common problems that arise when estimating the effects of tax changes on payout and investment:

- The tax cut affected some, but not all, firms incorporated in Switzerland. As we explain below, only firms with a certain type of reserves were allowed to pay tax-exempted dividends (hereafter TED) to their shareholders. As a result, we make use of a sample of control firms to filter out the effects of the business cycle on firms' payout and investment policy. Without such a control, it remains challenging to draw any causal inference between a tax change and observed outcomes (Chetty and Saez, 2005).

- The tax cut was unexpected - While initially targeting small and medium-sized enterprises, the 2011 fiscal reform also had some important unintended consequences on public firms. In particular, it allows some of them to pay TED. ${ }^{1}$

- The tax cut was sudden - Firms only had a few months to benefit from the tax cut in 2011 and several eligible firms were forced to wait until 2012 to benefit from it. ${ }^{2}$ As a result, Swiss companies were unable to anticipate the shock.

- The tax cut was massive - As the maximum marginal tax rate dropped from $36.2 \%$ to zero, this is the most important dividend tax cut we are aware of. Thus, the incentives implied by this reform are economically important. ${ }^{3}$

- The tax cut was permanent - The Swiss tax cut of 2011 was always presented as being permanent, unlike for instance the US tax cut of 2003 that carried a default expiration date after a few years. $^{4}$

- The overall reform includes no concurrent changes to the income tax or capital gains tax, and no other tax advantages on investments - Such concurrent changes would be a threat to the internal validity of the empirical design.

\footnotetext{
${ }^{1}$ The fact that public companies could pay TED came as a surprise and was never mentioned in the debates prior to the enforcement of the fiscal reform.

${ }^{2}$ As discussed below, the fact that some eligible firms had to wait for one more year to benefit from the reform is going to strengthen the identification strategy.

${ }_{3}^{3}$ As a mean of comparison, the top marginal federal dividend income tax rate went from $38.6 \%$ to $15 \%$ in the Jobs and Growth Tax Relief Reconciliation Act of 2003. As a result, one may wonder whether the investment inelasticity reported by Yagan (2015) may be due to too low an initial fiscal shock.

${ }^{4}$ As of today (November 2018), Swiss companies can still pay tax-exempt dividends and some firms have done so every year since 2011 .
} 
Given the key role played by the equity channel in the relationship between dividend taxes and investment, we focus in this paper on public firms, which turns out to be an advantage. Indeed, unlike private firms, public firms enjoy a direct access to equity markets. ${ }^{5}$ Furthermore, for private firms, dividends are just one component of the total compensation of shareholders as the latter are also often involved in the management of the firms and receive compensations. ${ }^{6}$ The actual breakdown between dividends and compensation mainly depends on the relative tax rates between the two types of payments. Fortunately, we do not have to worry about such substitution when dealing with public firms.

Our empirical analysis proceeds in three main steps and leads to the following findings. First, we study the impact of the tax cut on the payout policy of firms. By contrasting treated and control firms, both graphically and using regressions, we document that the reaction to the shock was immediate and both statistically and economically large. We find consistent results by considering various dimensions of the payout policy: dividend yield, dividend payout, total payout, as well as the percentage of firms paying dividends. Our findings remain robust when we shorten the sample period or change the composition of our sample by removing some firms (e.g. large ones, small ones, and financials). In an auxiliary test, we also contrast treated firms with others that, although being theoretically eligible, had to wait until 2012 before their eligibility was recognized by the Swiss Fiscal Authority. This group of firms constitutes an ideal control sample as they are similar to the firms treated in 2011 - they were just late by one year. We find consistent results in this alternative setting.

Second, we measure the real effects of the tax cut on firms' investments. Overall, we find no difference between the investment policies of treated and control firms in our sample. Not only we extend the conclusion of Yagan (2015) to public firms, but we also aim to identify the channel at play. We show that the absence of real effects can be attributed to a significant drop in retained earnings, which is caused by the increase in the total payout of treated firms. Indeed, we find that the rise in dividends is not compensated by an equally sized drop in share repurchases. Furthermore, treated firms do not raise enough capital, through seasoned equity offerings, to compensate for the contraction in retained earnings. We also show that the reduction in retained earnings is not compensated by a reduction in cash holdings. At least one

\footnotetext{
${ }^{5}$ Lack of access to equity financing is particularly problematic for the S-corps studied by Yagan (2015) as they are prevented by law from having any institutional equity financing and from having more than 100 shareholders. Other recent papers studying the effects of dividend tax cuts on private firms' financial decisions include Jacob and Michaely (2017) and Berzins, Bøhren and Stacescu (2018).

${ }^{6}$ For instance in Norway, $73 \%$ of the CEOs of the private firms studied by Berzins, Bøhren and Stacescu (2018) are members of the controlling family.
} 
of the two channels (equity and cash) has to be at play to generate the positive impact on investment that is typically promised by the politicians implementing such fiscal reforms.

Third, we show that reducing dividend taxes also has non-trivial implications for agency problems (Jensen and Meckling, 1976). We find that the treated firms that are the most exposed to agency concerns, as they have no monitoring blockholders and use dual-class share structure or voting right restrictions, are the most reactive to the tax cut. As they strongly and permanently reduce retained earnings after the tax cut, managers will end up with fewer resources to spend on wasteful projects. As a result, while politicians typically justify dividend tax cuts by promises of increased investment, consumption, and economic growth, our evidence suggests that the main advantage of tax cuts for society may lie somewhere else: they mitigate agency problems within firms.

Our main contribution to the literature is to identify and exploit a unique set-up allowing us to provide a more clear-cut answer to the important, and so far unsettled, question of the effects of dividend taxes on firms' payout and investment policy. We believe our identification strategy to be as close as it gets from a proper controlled experiment, which allows us to make causal statements about the financial and real effects of corporate taxes. Furthermore, our study is to the best of our knowledge, the first empirical study on the effects of a dividend tax cut on public firms using a control sample of unaffected, yet similar, firms. ${ }^{7} \mathrm{~A}$ final contribution is to document empirically a channel between dividend taxes and agency costs within public firms.

The rest of the paper is organized as follows. In Section 2, we derive our testable hypotheses from standard corporate finance theories. We present in Section 3 the Swiss corporate tax system and the fiscal shock we focus on. We describe our data in Section 4. Section 5 presents the effects of the dividend tax cut on the payout and investment policy of Swiss companies and Section 6 discusses the implication of the tax cut for agency problems. Finally, Section 7 concludes our study.

\section{THEORY AND TESTABLE HYPOTHESES}

The neoclassic theory of corporate dividend taxation, known as the "old view", states that reducing dividend taxes mechanically reduces the firms' cost of equity and boosts investment (Harberger, 1962, 1966; Feldstein, 1970; Poterba and Summers, 1985; Poterba, 2004). In this

\footnotetext{
${ }^{7}$ Chetty and Saez (2005) also study public firms but their "control sample" was made of treated firms which, given their ownership structure, were supposed to be less affected by the tax cut.
} 
theory, the marginal source of funds for investment is the new shares issued. Reducing the tax rates on dividends lowers the required rate of the return of shareholders, which is the cost of equity of the firm. This drop in the cost of equity mechanically turns the Net Present Value (NPV) of some investment projects from negative to positive, hence boosting capital expenditures. Such an increase in investment is funded by raising new equity, typically through seasoned equity offerings.

According to this theory, dividend payout is not supposed to react to a tax cut in the shortrun but it should increase with time, once the positive effects of the new investments have materialized. Firms may, however, decide to immediately increase their dividend to signal that their earnings are expected to increase in the future (Bernheim, 1991). Similarly, in the agency model of Chetty and Saez (2010), a dividend tax cut leads to an immediate increase in dividend payments because it increases the manager's preference for dividends relative to unproductive investments, and especially so if the manager also owns equity. In order to test the aforementioned theories, we state our first hypothesis:

\section{H1: Dividend payout increases after a dividend tax cut.}

Other standard theories claim that H1 should not hold. For instance, the "new view" developed by King (1974), Auerbach (1979), Bradford (1981), and Auerbach (2002) concludes that dividend taxes should have no impact on dividends and investment. Under this view, even if the firm distributes all its earnings to its shareholders, it can still fund its positive NPV projects with cash and without having to issue new equity. The shareholders are indifferent between the distribution now and the distribution in the future because both shareholders and the corporation are assumed to invest at the same market rate.

Furthermore, to study the impact of a dividend tax cut on retained earnings, and ultimately on investment, one also needs to take into account share repurchases. In general, a share repurchase offers an attractive alternative to cash dividends as the generated cash flows are taxed as capital gains, unlike dividends. Whenever dividends are taxed more heavily than capital gains, lowering the dividend tax rate should trigger a substitution between dividends $(\uparrow)$ and share repurchases $(\downarrow)$. In order to assess the net effect of the changes in cash dividends and share repurchases, we formulate the following hypothesis:

\section{H2: Total payout increases after a dividend tax cut.}


$\mathrm{H} 2$ corresponds to a situation where dividends are more reactive with respect to the tax cut than share repurchases. In other words, the positive change in dividends dominates the negative change in share repurchase. If reducing dividend taxes leads to a higher total payout, it also mechanically reduces the retained earnings $(\Delta \mathrm{R}<0)$ available to fund new investments (Doidge and Dyck, 2015). In such a case, in order to be able to increase investment, firms must simultaneously raise equity $(\Delta \mathrm{E}>0)$. This is the main channel in the neoclassical model of dividend taxes as the tax cut is supposed to mechanically reduce the cost of equity. Alternatively, the firm can use its cash holding $(\Delta \mathrm{C}<0)$ to fund the new investments. We test the funding channel of the new investment using the following hypothesis:

\section{H3: Firms raise equity and/or decrease their cash holdings after a dividend tax cut.}

Even if $\Delta \mathrm{E}>0$ and $\Delta \mathrm{C}<0$, we still need to have $\Delta \mathrm{E}+|\Delta \mathrm{C}|>|\Delta \mathrm{R}|$ for the firm to have the necessary financial resources to increase investment. In other words, the increase in equity, adjusted for cash, has to dominate in absolute value the drop in retained earnings. Hence, raising equity is not a sufficient condition to spur corporate investment. In order to test the net effect of a dividend tax cut on investment we formulate our final hypothesis:

\section{H4: Firm's investment increases after a dividend tax cut.}

This last hypothesis is going to be central in our study as it allows us to contrast the two main theories of dividend and corporate taxes (old and new views), and test whether corporate tax shocks have any real effect on the economy. Before we formally test these four hypotheses, we provide some information about the Swiss tax system, the natural experiment we consider in this paper, and our data. We do so in the next two sections.

\section{CORPORATE TAXES IN SWITZERLAND AND THE NATURAL EXPERIMENT}

\subsection{The Swiss corporate tax system}

This section describes the tax treatment of dividends, share repurchases, and capital gains for the various types of shareholders in Switzerland. There are two main features of the Swiss corporate tax system that one needs to be aware of. First, whenever a Swiss corporation pays dividends to its shareholders (domestic and foreign), it has to directly pay a withholding tax to the fiscal authorities that corresponds to $35 \%$ of the amount of dividends, i.e., investors only receive $65 \%$ of the gross dividend. They then have to claim back the withholding tax once they 
have declared and paid taxes on their income. ${ }^{8}$ Second, taxes must be paid at the municipal, cantonal (state), and Federal levels and, consequently, the overall fiscal burden depends on the domicile of the fiscal subject. This multi-layer system is similar to the US tax system in which individuals not only have to pay Federal taxes but in most cases also state and municipal taxes on income and dividends.

In Switzerland, taxes on dividends depend on the fiscal status of the shareholder who receives them. There are four different types. The first three correspond to categories of domestic investors whereas the last one applies to investors who do not have their legal domicile in Switzerland.

- Individual investors: Dividends are taxed as ordinary income while capital gains are not taxed. ${ }^{9}$ The top marginal personal income tax rate was $36.3 \%$ for this category of investors. ${ }^{10}$

- Corporations: Dividends on stocks held by corporations are taxed as ordinary corporate income. Capital gains are taxed at the same rate, i.e., $21.2 \% .{ }^{11}$ If a company holds more than $20 \%$ of the equity of another company, it benefits from a tax reduction on dividends.

- Tax-exempted investors: Institutional investors, such as pension funds and investment funds, do not pay taxes on dividends and capital gains. Other tax-exempted shareholders include government organizations at any level (Federal, cantonal or municipal), charitable organizations, and international organizations.

- Foreign investors: Dividends distributed to foreign investors are subject to the $35 \%$ withholding tax. Foreign investors can then reclaim this tax if they declare these revenues in their home country and if their country has signed an agreement with Switzerland in order to avoid double taxation.

As there are no taxes on capital gains in Switzerland, share repurchases appear a priori as a more tax-efficient way for a firm to transfer cash to shareholders. However, the tax treatment of share repurchases depends on the goal of the share repurchase program. On the one hand, if firms keep the repurchased shares as treasury stocks (to use them at a later date) then they are

\footnotetext{
${ }^{8}$ The withholding tax system is not unique to the Swiss setting and can be found in the United States and in 23 out of the 28 European Union member states. However, in contrast to most of these countries, the withholding tax in Switzerland is not limited to foreign entities but applies to all investors whether domestic or foreigners.

${ }^{9}$ There is an exception for individuals obtaining more revenues from trading securities than from their own labor income. Fiscal authorities treat these individuals as professional traders and impose capital gains as income.

${ }^{10}$ Source: OECD Tax database website. This rate is for an investor located in the city of Zurich for the year 2010.

${ }^{11}$ Source: OECD Tax database website. This rate is for a firm located in the city of Zurich for the year 2010.
} 
taxed as capital gains and they are an attractive alternative to dividends. On the other hand, if companies repurchase shares in order to cancel them, the difference between the repurchase price and the nominal value of the stock is taxed at the same rate as a dividend. ${ }^{12}$

\section{[Insert Figure 1 here]}

We see in Figure 1 that dividends are the dominant form of payout in Switzerland. Even if dividends are known to be sluggish at the firm level, aggregate dividends fluctuate according to the business cycles (see Panel A). For instance, the drop in the payout of Swiss companies between 2007 and 2009 corresponds to a period of weak economic conditions, and even to a period of negative GDP growth between 2008Q3 and 2009Q1. The impact of this recession was more severe on the investment of Swiss companies as the fixed gross capital formation dropped by CHF5 billion (-15\%) over the same three quarters. The sensitivity of both payout and investments to business-cycle conditions reinforce the importance of having a control sample (as we do) when testing the effect of a fiscal shock on payout and investments. Otherwise, observed swings in dividends or investments could be wrongly attributed to the fiscal shock. We also see in Panel A that share repurchases account for an important part of aggregate payout of Swiss companies. When expressed as a percentage of aggregate dividends, repurchases also exhibit important significant time variation: from as high as $99.1 \%$ in 2003 to as low as $6.8 \%$ in 2013 .

Panel B shows that the fraction of firms paying dividends increased steadily until the great recession, with a maximum of $63 \%$ of the firms paying dividends in 2008 . Then it dropped in 2009-2010, and rebounded to pre-crisis levels after 2012. We notice that, while repurchases account for a significant fraction of total payout, it is not a widespread phenomenon across public firms in Switzerland. Indeed, on average, only 6.5\% of Swiss corporations repurchase their shares in a given year. This contrasts with the behavior of publicly listed firms in the US. Over the same period, the proportion of US public firms repurchasing their stocks ranges between 30 and 40\% (Farre-Mensa, Michaely and Schmalz, 2014).

\footnotetext{
${ }^{12}$ Since the tax is not calculated on the difference between the repurchase price and the price paid by the investor to buy the share, this creates an important fiscal disadvantage for taxed investors. This is due to the fact that the nominal value is much lower than the current stock market price (on average less than 1\%) and therefore the basis on which the tax burden is computed is much larger than just the capital gain (Chung, Isakov and Pérignon, 2007).
} 


\subsection{The Natural Experiment}

The possibility to pay TED in 2011 was an unintended consequence of the second Corporate Taxation Reform (CTR2) proposed by the Swiss Federal government. ${ }^{13}$ As stated by the Federal government, the main objective of this reform was to lower the tax burden on corporations to favor economic growth and stimulate employment. For instance, the Federal Council states that CTR2 "aims to improve the fiscal conditions for small and medium sized companies" and "to lower the fiscal burden that distort business decisions, and to boost economic growth and employment".

Specifically, the three main changes to the Swiss corporate tax system are:

- To reduce the fiscal burden on firms' capital, CTR2 introduces the capital contribution principle, which allows Swiss firms to exempt from withholding and income taxes the repayment of capital contributions made by the direct shareholders. This change aims to eliminate the particularly unfavorable tax treatment of exits by shareholders of small and medium-sized enterprises - hence hurting equity issuance in the first place.

- To dampen the double taxation of corporate earnings, CTR 2 exempts $40 \%$ of the dividend payed to any physical person or firm owning at least $10 \%$ of a given firm. Before CTR2, the threshold was at $20 \%$. Such large equity stakes are a common feature among small and medium-sized enterprises.

- To simplify the reorganization and transfer of small and medium-sized enterprises, CTR2 fully exempts from taxes any cash flows coming from the sale of production factors, such as vehicles or pieces of equipment. It also improves the tax treatment on corporate transfers or liquidations.

The CTR2 bill was approved by the Swiss Parliament on April 13, 2007 and eventually enforced on January 1, 2011. ${ }^{14}$ Prior to this date, the Swiss government always presented the capital contribution principle as applying only to small and medium-sized enterprises. However, on December 9, 2010, or 23 days prior to the enforcement date of CTR2, the Swiss Federal Tax Authority published a circular describing in great detail the conditions under which

\footnotetext{
13 The first Corporate Tax Reform (CTR1) took place in 1997, hence 10 years before the starting date of our sample period. The third Corporate Tax Reform (CTR3) has been accepted by the Swiss parliament in June 2016 but it was eventually rejected in February 2017 by the Swiss people in a referendum.

${ }^{14}$ The entry into force of the new bill was postponed because a coalition of political parties launched a referendum against the new law on the ground that it would lead to substantial revenue losses for the Federal Government. Eventually, the Swiss people accepted the new law on February 24, 2008 with a short majority of 50.8\%.
} 
capital contributions could be tax-exempted. In this document, the Federal Tax Authority explicitly considered the case of paying tax-exempted dividends out of capital contribution, a case never mentioned in the preceding debates. Consequently, all firms incorporated in Switzerland that were able to prove the existence of capital contributions were allowed to distribute TED to their shareholders from their paid-in capital. ${ }^{15}$ A capital contribution is defined as the difference between the market price and the nominal value a shareholder pays. Such contributions are made either at the time of the Initial Public Offering, when new shares are issued, or when executives and employees exercise their stock options. ${ }^{16}$

Since the possibility to pay tax-exempted dividends came as a surprise in December 2010, and the deadline to get the capital contributions approved by the Federal Tax Authority was very short, only a fraction of eligible companies could use this possibility in $2011 .{ }^{17}$ Actually, $46 \%$ of all listed companies had some reserves from capital contributions recognized in 2011 while an additional 20\% had some reserves recognized in 2012. As a result, the introduction of the capital contribution principle in 2011 creates a natural experiment setting as the possibility to pay tax-free dividends was unexpected. We assign firms to the treatment group if they had recognized reserves from capital contribution in 2011 and were authorized to pay taxexempted dividends. Firms are in the control group if they did not have such reserves recognized by the Federal Tax Authority and hence could not pay TED in 2011. Moreover, the allocation of firms into one of the two groups appears to be quite exogenous as one cannot argue that firms increased their capital, made an Initial Public Offering or granted stock options on purpose since it was virtually impossible to predict the actual scope of this piece of legislation.

The introduction of the tax-exemption of dividends sparked a heated political debate in the country. Several members of the Swiss Parliament tried to cancel the vote claiming that the government had not properly informed the citizens. In December 2011, the Swiss Supreme Court rejected the appeal and confirmed the new law but blamed the Federal Council for having improperly informed citizens before the vote.

\footnotetext{
15 The tax break for investors investigated in this paper applies to all Federal, cantonal, and municipal taxes.

${ }^{16}$ Only capital contributions from January 1, 1997 onwards were eligible for tax-free repayment from 2011 onwards. Capital contributions had to be presented to the Federal Tax Authority at the latest 30 days after the approval of the 2011 fiscal year accounts. In order to do so companies had to go through their capital contributions for fiscal years 1997-2010, fill out a form to be sent to the Federal Tax Authority and justify their demand for the creation of a capital contribution account.

${ }^{17}$ Swiss companies are legally obliged to have their annual meeting at the latest six months after their fiscal year end. In our sample, $90.1 \%$ of the firms have their fiscal year-end on December 31 and must therefore hold their annual meeting before the end of the following June.
} 


\section{DATA AND SUMMARY STATISTICS}

Our sample of firms includes all constituents of the broadest stock index in Switzerland, the Swiss Performance Index, between 2007 and 2015. On any given year, the index is made of around 200 firms traded on the SIX Swiss exchange. To be included in our sample, a firm has to be part of the index for at least one year. Consequently, we end up with an unbalanced panel of 264 companies, ranging from large, multi-billion multinationals (e.g. Nestlé, Novartis, UBS) to smaller, more local firms. ${ }^{18}$ Focusing on the major stock index' constituents allows us to discard companies with a very low free float, open-end funds, or foreign firms that are crosslisted in Switzerland. The latter would unlikely qualify as appropriate control firms in our empirical tests.

While our analysis requires precise information on the tax status of the dividends for each firm/year, this information is typically not included in standard financial databases. We therefore hand-collected such information from the companies' annual reports and systematically cross-checked it with the Swiss stock guide. ${ }^{19}$ In particular, we collected the yearly dividend paid per share as well as its tax status: taxed or tax-exempted. ${ }^{20}$

We also collected detailed data on the share repurchase activities of all sample firms from the Swiss Takeover Board (http://www.takeover.ch), which is the supervisory authority overseeing repurchase activities in Switzerland. Data on the length of the program and repurchase methods were also collected from the Swiss Takeover Board website. The actual amounts repurchased by firms were obtained from the firms' websites/annual reports, and the website of the Swiss stock exchange (www.six-swiss-exchange.com).

Furthermore, all accounting data for our sample firms were obtained from Worldscope. An exception is the reserves from capital contribution giving the right to pay TED, which had to be hand collected from the firms' annual reports. Moreover, stock price data were obtained from Datastream.

\footnotetext{
${ }_{18}$ When studying investment (capex) and financing options, we exclude financial firms from the sample. Differently, in our tests on payout, we estimate the specifications with all firms and with non-financial firms only. We believe including financial firms can be interesting in our setting as all financial firms in Switzerland, including state-owned banks, can freely choose their dividend policy.

${ }^{19}$ The Swiss stock guide is an annual publication presenting for all Swiss public firms a large number of financial information in a standardized format.

${ }^{20}$ Swiss firms pay dividends once a year.
} 
Finally, we collected ownership data from the firms' annual reports. For each firm, we have data on the identity and holdings of all shareholders having more than $3 \%$ of voting rights. We then classify firms in different categories. A firm is said to be widely held if it does not have a shareholder holding more than $10 \%$ of the voting rights. If the largest shareholder of a company has more than $10 \%$ of voting rights, the firm is considered to be owned by a controlling shareholder. For $63 \%$ of these firms, the blockholder is a family whereas for the remaining $37 \%$, the blockholder is either the State, another corporation, a pension fund, or a foundation.

We report in Table 1 some summary statistics about all sample firms in the year preceding the enactment of the reform (2010). All firm characteristics and investment variables are winsorized at the $1^{\text {st }}$ and $99^{\text {th }}$ percentiles. In our sample, around $70 \%$ of the firms pay a cash dividend to their shareholders and the average dividend yield is $2.03 \%$. On average, a typical firm pays out $34.78 \%$ of its earnings in dividends, and $36.31 \%$ in dividends and/or share repurchases. $^{21}$

When splitting our sample between treated and control firms, we end up with two groups that are well balanced in terms of size (114 vs. 96 firms) and remarkably similar in terms of composition. Indeed, treated and control firms look very much alike as far as payout, firm characteristics, investment, and ownership are concerned. For instance, the dividend yield is $2.07 \%$ for treated firms vs. $1.99 \%$ for control firms, and the total payout is $37.19 \%$ for treated firms vs. $35.58 \%$ for control firms. Moreover, prior to the reform, $67.71 \%$ of the treated firms were paying dividends vs. $70.18 \%$ of the control firms. As for investment, the capex-to-PPE (Property, Plant \& Equipment) ratio is $20.68 \%$ for treated firms vs. $17.35 \%$ for control firms, and the cash-to-total-assets ratio is $17 \%$ for treated firms vs. $16.5 \%$ for control firms. For all considered variables, we cannot reject the null hypothesis that treated and control firms have the same mean.

There are two dimensions though for which the two subsamples differ. The first one is size, as measured either by total assets or book value of equity, for which treated firms appear to outsize their peers. This is due to the fact that the size distribution of Swiss companies is skewed and that the largest ones tend to be treated. ${ }^{22}$ The second one is the fraction of firms that are

\footnotetext{
${ }^{21}$ Following Julio and Ikenberry (2004) and Von Eije and Megginson (2008), payout ratios are set to $100 \%$ if they are negative or if a firm distributes more than $100 \%$ of its earnings.

${ }^{22}$ If we proxy firm size by market capitalization instead of total assets, treated firms are not larger than control firms anymore. This is due to the fact that the market capitalization of the largest Swiss banks was very low compared to their book value of equity.
} 
widely-held as this feature is more common among treated firms: $40.43 \%$ vs. $28.07 \%$ for control firms.

[Insert Table 1 here]

\section{EFFECTS ON PAYOUT POLICY AND INVESTMENT}

\subsection{Payout Policy}

We start our investigation on the effect of removing dividend taxes by comparing the evolution of the main payout variables for firms affected by the reform (treated firms) and those that are not (control firms). As explained in Section 3, to be treated, a firm must have some reserves from capital contributions that have been recognized by the fiscal authorities in 2011 . On the other hand, control firms do not benefit from the dividend tax cut and can only pay taxed dividends to their shareholders. This setting allows us to cleanly assess the impact of removing the dividend tax on firms' financial decisions.

[Insert Figure 2 here]

Figure 2 displays the evolution of the average dividend yield, average dividend payout, and of the fraction of dividend-paying firms, using the following definitions:

$$
\begin{aligned}
\text { dividend yield }_{i t} & =\frac{\text { dividend per share }_{i t}}{\text { stock price }_{i t}} \\
\text { dividend payout }_{i t} & =\frac{\text { dividend per share }_{i t}}{\text { earnings per share }} i t \\
\% \text { of dividend paying firms } & =\frac{\# \text { of dividend paying firms }}{t}
\end{aligned}
$$

The evidence in Figure 2 is remarkable. Indeed, before the introduction of CTR2, both control and treated firms behave similarly. On the first year of the reform (2011), treated firms sharply increase their dividend yield while it remains quite stable for control firms. The economic magnitude of the effect appears large. Interestingly, we obtain consistent results when looking at the other two dimensions of the firms' dividend payout. Furthermore, the 
evolution of the curves after the tax cut also suggests that the effect seems to be fairly persistent over time. We complement our analysis by analyzing total payout, which we define as:

$$
\text { total payout }_{i t}=\frac{\text { dividend per share }_{i t}+\text { amount per share spent for repurchases }_{i t}}{\text { earnings per share }}
$$

Accounting for share repurchases allows us to have a full picture of the payout policy of the firms. We also display the evolution of this additional variable in Figure 2 and see that going from dividend payout to total payout does not materially affect the overall pattern. The payout ratio of treated and control firms follows a common trend prior to the reform and their evolution diverges significantly afterwards. ${ }^{23}$

We then formally contrast the payout policy of treated and control firms using a differencein-differences setting. We estimate the following specification using OLS regressions and robust standard errors clustered at the industry level:

$$
y_{i t}=\alpha+\beta \cdot \text { treated }_{i t}+\boldsymbol{\gamma}^{\prime} \mathbf{X}_{i t}+F E_{i}+F E_{t}+e_{i t}
$$

where $y_{i t}$ is a payout variable, treated $_{i t}$ is a dummy variable taking the value of one if the firm is treated and the year is equal or after $2011, \mathbf{X}_{\mathbf{i t}}$ is a vector of control variables, and $F E_{i}$ and $F E_{t}$ are firm and year fixed effects.

Such a specification appears particularly appropriate in our setting as the payout variables of treated and control firms follow a common trend prior to the fiscal shock (see the 2007-2010 subperiod in Figure 2). Estimation results in Table 2 indicate that treated firms tend to increase dividend and total payout following the fiscal shock (columns 1, 3, 5, and 7). The beta coefficient is both statistically significant at the $99 \%$ confidence level and economically significant. It means that treated firms increase their dividend yield after the tax cut by $0.672 \%$ more than control firms. This is a sizable increase as the unconditional average of the dividend yield is around $2 \%$ over our sample period. When turning to the three other payout variables,

\footnotetext{
${ }^{23}$ For completeness, we also study other payout variables considered in the literature (see Chetty and Saez, 2005): the percentage of firms starting to pay a dividend (first timers) and the percentage of firms increasing their dividends compared to the previous year. Both variables are significantly higher for treated firms in 2011 but are comparable in magnitude over the 2012-2015 period. Note that the effect is not expected to be permanent for these variables as a given firm cannot, by definition, initiate dividend payment two years in a row, and the second variable is in first-difference and not in level.
} 
the pattern remains very similar: the payout ratios and the propensity to pay a dividend increase significantly more for treated firms after the tax cut.

\section{[Insert Table 2 here]}

In order to reinforce the causal explanation between the tax cut and payout policy, and to better understand the dynamics of the payout policy around the fiscal shock, we estimate an alternative specification in which we treat each year separately:

$$
\begin{gathered}
y_{i t}=\alpha+\beta_{-1} \cdot \text { treated }_{i t}(-1)+\beta_{0} \cdot \text { treated }_{i t}(0)+\beta_{1} \cdot \text { treated }_{i t}(+1) \\
+\beta_{2} \cdot \text { treated }_{i t}(2+)+\gamma^{\prime} \mathbf{X}_{i t}+F E_{i}+F E_{t}+e_{i t}
\end{gathered}
$$

where treated $_{i t}(-1)$ is a dummy variable taking the value of one if the firm is treated and the year is 2010 , $_{\text {treated }}(0)$ is a dummy variable taking the value of one if the firm is treated and

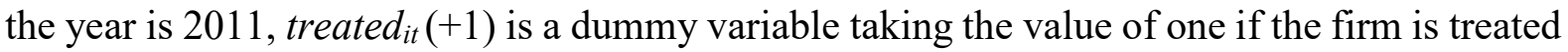
and the year is 2012 , and treated $_{i t}(2+)$ is a dummy variable taking the value of one if the firm is treated and the year is 2013,2014 , or 2015 .

Such a specification allows us to get a better sense of the gradual adjustment of the payout policy of the firms and to test whether the effect is persistent. It also allows to detect, or rule out, any potential anticipation effect. The results in columns $2,4,6$, and 8 of Table 2 clearly show that most of the increase occurs on the first year of the reform (year 0), which is consistent with the visual analysis of Figure 2 . The non-significant $\beta_{-1}$ coefficients indicate that there is no anticipation, which points toward a causal explanation. Moreover, both the estimated values and t-stats of the $\beta_{1}$ and $\beta_{2+}$ coefficients collectively indicate that the effect of the tax cut on dividends is not short-lived.

We conduct a series of additional tests and robustness checks. A first potential source of concern is the fact that some control firms did react to the fiscal shock during the post-reform period. Indeed, some firms started building reserves from capital contributions to be able to pay some TED to their shareholders. To take care of this concern, we drop these "switching firms" from the analysis and re-estimate both equations (1) and (2). Doing so leads to a reduction in the number of observations from 1,857 to 1,680 , but it does not materially change the overall pattern. We see in Table 3 that the coefficient associated to the treatment variable 
remains positive and statistically significant at the $99 \%$ confidence level (columns 1, 3, 5 and 7), and the estimated dynamics remains virtually unaffected (columns 2, 4, 6 and 8).

An alternative way to deal with switching firms is to terminate the sample period at the end of year 0 . Doing so allows us to design a particularly clean test of the effect of removing dividend taxes on firm payout, but it comes at the cost of reducing both sample size and statistical power. We present the estimation results in columns 1, 3, 5 and 7 of Table 4 . The estimated beta coefficients remain statistically significant at the $90 \%$ or $95 \%$ confidence levels for the first three variables (columns 1, 3 and 5), but their values are smaller than when we consider the full five years after the tax cut. The latter is consistent with the fact that the effect was building up over the three years following the event. For the percentage of payers, the $\beta$ coefficient on the treatment dummy remains positive and statistically significant at the $90 \%$ confidence level. However, in this case, there is no drop in the value of the coefficient compared to Table 3 as the full adjustment is made after one year.

\section{[Insert Tables 3 and 4 here]}

In an auxiliary test, we exploit a specific feature of our set-up. Indeed, firms had little time between the announcement of the possibility to pay TED (December 2010) and their next general assembly (typically between March and May 2011). Indeed, some firms with potential reserves from capital contributions did not have enough time to file their request with the Federal Tax Authority and to get its approval in due time. As a result, such firms, although being theoretically eligible, had to wait an extra year to benefit from the tax cut. From an identification point of view, these "late firms" constitute an ideal control sample as they are similar to the firms treated in 2011. Our setting looks, in some respects, like the one used by Bernstein (2015) in his study of the effects of going public on firms' innovation. He contrasts long-run innovation firms that filed to go public in the same year, but experienced different post-filing stock market returns. Just like in the present test, these two groups of firms are ex ante similar and offer a clear identification strategy. Columns 2, 4, 6 and 8 in Table 4 display the regression results for treated firms vs. late firms over the sample period 2007-2011. In this case too, we find that firms quickly and massively adjusted their payout policy after the tax cut. 
As an additional robustness check, we remove all firms belonging to the financial industry. This reduces our sample size from 1,857 to 1,336 observations. We estimate equations (1) and (2) with non-financial firms only and report the results in Table 5. Regardless of the payout variable, we obtain consistent results, which suggests the base line results are not materially affected by the presence of financial firms. ${ }^{24}$

Finally, as our sample is very heterogeneous in terms of size with some small local companies and multinational firms, we redo our tests after removing the bottom and top quintile of firms in terms of total assets. Results in Table A3 (in the Appendix) indicates that our findings are not driven by the smallest or the largest firms.

Overall, the evidence presented above hints at a strong impact of dividend taxes on the payout policy of firms, which comes in contrast with the often alleged minor effect of corporate taxes (Myers, McConnell, Peterson, Roebuck, Soter, Stewart and Stern, 1998). More specifically, we cannot reject the first two hypotheses (H1 and H2) according to which a dividend tax cut increases both dividend payout and total payout. This empirical evidence is consistent with previous evidence for private firms (Yagan, 2015; Alstadsæter, Jacob and Michaely, 2017; Jacob and Michaely, 2017). Hence, our findings contradict both the neoclassic and new view of dividend taxes according to which payout policy is independent of dividend taxes. It is then more in line with theories that imply that reducing dividend taxes lead firms to immediately increase dividends, such as the signaling model of (Bernheim, 1991) or the agency model of Chetty and Saez (2010).

\section{[Insert Table 5 here]}

\subsection{Investment Policy}

We now analyze whether the introduction of CTR2 had any effect on the investment policy of Swiss companies (Hypothesis H4). Our measure of corporate investment is the ratio of capital expenditures scaled by lagged fixed assets (property, plant and equipment). This ratio is widely used in the empirical corporate finance literature (e.g. Almeida and Campello (2007) or Foucault and Fresard (2014)) to represent firm investment levels. As with the payout variables in Section 5.1, we start by plotting the evolution of the capex-to-PPE ratio. We observe in Figure 3 that prior to the reform, the evolution of this investment variable was

\footnotetext{
${ }^{24}$ In Tables A1 and A2, we replicate Tables 3 and 4 using non-financial firms only and obtain similar results.
} 
remarkably similar for both treated and control firms. Unlike for payout, we visually do not detect any increase in average investment for the treated firms after the enactment of the reform. If anything, the average investment is increasing only for control firms 2-3 years after the tax cut. Differently, for treated firms, the negative trends initiated after the 2008 crisis continues after the introduction of CTR2.

Next, we estimate Equation (1) using the natural logarithm of capex and the ratio of capexto-PPE as the endogenous variable. For each variable, we estimate the four specifications that we used for the payout variables in Section 5.1. Specifically, we contrast treated and control firms over the whole sample (columns 1 and 5), treated and control firms, except "switching firms", over the whole sample (columns 2 and 6), contrast treated and control firms over 20072011 (columns 3 and 7), contrast treated firms with "late firms" over the 2007-2011 (columns 4 and 8). We report the regression results in Table $6 .{ }^{25}$ Overall, we do not detect any significant effects of the tax cut on the investment of treated firms. This set of results indicate that the CTR2 did not meet one of its main objective, which was to produce positive real effects.

[Insert Figure 3 and Table 6 here]

Our results are in line with Yagan (2015) who reports that the 2003 dividend tax cut had no material effect on the investment policy of private firms in the US. This body of evidence clearly contradicts neoclassical models which focus on the role of equity and on its reduced cost following any tax cut. In order to better understand why reduced taxes on dividends did not materialize into more investment, we test (1) whether treated firms raise equity and/or (2) whether they reduce their cash holdings more than control firms. We display in Figure 3 the percentage of firms that increase their equity (book value) on a given year. In this figure, there is no indication that treated firms are more prone to raise equity than their peers after the tax cut.

We complement this visual analysis using a series of regression analyses. The estimation results in Table 7 confirm that treated firms do not significantly increase their equity and do not significantly reduce their cash holdings. ${ }^{26}$ Given the fact that, at the same time, we also

\footnotetext{
${ }^{25}$ In Table A4, we re-estimate our specifications on investment using different winsorizing thresholds and obtain similar results.

${ }^{26}$ In Table A5, we re-estimate our specifications on equity and cash using different winsorizing thresholds and obtain similar results.
} 
report a sudden and large increase in total payout, the residual financial resources available to finance new investment is mechanically shrinking.

[Insert Table 7 here]

Overall, our findings in this section allow us to reject both Hypotheses H3 and H4 and provide the following message. Reducing the dividend tax has two main impacts: First, it lowers the cost of equity for treated firms, which tend to increase their investment. Second, it increases total payout or, in other words, reduces retained earnings available to engage in new investments. The net effect of these two opposite forces is unknown a priori and becomes an empirical question. In our setting, we conclude that none of the two effects really dominates the other one, and the net effect is null or very small.

\section{IMPLICATIONS FOR AGENCY PROBLEMS}

We have seen in the previous sections that reducing dividend taxes induces firms to significantly increase their dividend payout. But because dividends remove corporate wealth from insider control, changing dividend taxes should also impact the level of agency problems (Jensen, 1986). In this section, we illustrate empirically this phenomenon, which can be seen as an unintended consequence of the dividend tax cut. In particular, we see that the reduction in available retained earnings is strongest for firms that are most exposed to agency problems.

The question of whether dividend taxes affect agency problems appears particularly interesting in our setting. In terms of corporate governance, Switzerland belongs to the German-origin civil law countries which tend to have poor investor protection (La Porta, Lopez de Silanes, Shleifer and Vishny, 1998). This is illustrated by Switzerland ranking quite low in terms of the anti-director rights index (La Porta, Lopez-de-Silanes, Shleifer and Vishny, 1998), anti-self-dealing index (Djankov, La Porta, Lopez-de-Silanes and Shleifer, 2008), or corporate governance ratings (Doidge, Karolyi and Stulz, 2007; Aggarwal, Erel, Ferreira and Matos, 2011).

Different types of agency problems can arise in our setting. In widely held firms, there is a conflict of interest between shareholders and management as the shareholders do not have the capacity and incentive to properly monitor the managers. Managers may potentially exert 
insufficient effort, engage in wasteful investment, pay themselves compensation and enjoy various perks, which eventually destroy firm value. Differently, in firms having a controlling shareholder, agency problems materialize through a conflict of interest between majority and minority shareholders. Agency problems are less severe in those firms as a large shareholder has strong incentives to closely monitor the management team (La Porta, Lopez-de-Silanes, Shleifer and Vishny, 2000).

Nevertheless, the controlling shareholder can potentially extract private benefits from outside shareholders. In addition to ownership structure, differences in the severity of agency problems can also be related to the use of control-enhancing mechanisms (CEM). Swiss firms mainly use two such mechanisms: multiple share classes and voting right restrictions. The former allows the controlling shareholder to have more control rights than cash-flow rights and the latter represents an anti-takeover mechanisms (in practice, the limit is set between 2 and $10 \%$ ). Both mechanisms aim to limit shareholder democracy and give more power to the controlling shareholder and/or the management of the firm. The use of CEM leaves more freedom to insiders and is potentially associated with more agency problems. Note that $39 \%$ of firms in our sample have one of these two kinds of CEM. Our tests exploit the cross-sectional variations in the level of agency problems proxied by ownership concentration or the use of CEM.

We start by contrasting the reaction to the tax cut of two types of treated firms: those that are widely-held (19.2\% of the sample) and those which have one or several blockholders ( $80.8 \%$ of the sample). We estimate a variation of Equation (1) in which we break the treated variable down into two variables: one that takes a value of one if the treated firm is widelyheld and another one that takes a value of one if the treated firm has a blockholder. ${ }^{27} \mathrm{We}$ see in Table 8 that the value of the beta coefficients on the treatment variables is positive and statistically significant for both types of firms, which suggests that the effect documented in Section 5 is widespread among all types of public firms. However, the value of the beta coefficient is much higher for widely-held firms. For instance, when modelling dividend yields in column 1 , the beta coefficient is $66 \%$ higher for widely-held firms than for firms with a blockholder. We obtain consistent results when using dividend and payout ratios and the percentage of dividend payers (columns 3, 5 and 7) for which the difference in betas are respectively equal to $57 \%, 51 \%$, and $251 \%$. This first set of results indicates that firms

\footnotetext{
${ }^{27}$ We define blockholders using a 10\% threshold but we consider other thresholds in our robustness checks.
} 
associated with higher agency costs (i.e., widely-held firms) increase their payout significantly more than firms associated with lower agency costs (i.e., firms with a blockholder).

The results are presented in columns 2, 4, 6 and 8 of Table 8 . For widely-held firms, we observe that CEM are associated with a stronger reaction to the tax cut. We see in Table 8 that, for three out of the four payout variables, the beta coefficient is indeed higher for firms with CEM. This suggests that the firms that are more prone to severe agency problems, namely those without any blockholder and with control enhancing structures in place, are the ones that increase the most their payout. By doing so, they decrease the available retained earnings the most and therefore leave less room for agency problems to materialize. These findings are consistent with results in Berzins, Bøhren and Stacescu (2018) for private Norwegian firms.

When turning to firms with blockholders, the situation is opposite. The beta coefficient is only significant for firms associated with lower agency costs (i.e., firms with a blockholder and no CEM). Differently, firms that have both a blockholder and some CEM in place do not

significantly change their payout policy after the tax reduction. Our interpretation of this result is that these blockholders have the full control over the firm as they have the absolute majority of voting rights. After the tax cut, these firms do not increase payout and keep the level of retained earnings constant, which might be detrimental to outside shareholders.

[Insert Figure 4 and Table 8 here]

\section{CONCLUSION}

The distortive effect of corporate taxes is a fundamental problem in both corporate and public finance. In this paper, we contribute to the important debate on the impact of dividend taxes on corporate decisions by focusing on the 2011 corporate tax reform in Switzerland. This reform gives us a quasi-experimental set-up as some firms were suddenly able to pay taxexempted dividends while others were not.

The main findings from our study are the following. We find that treated firms immediately and massively increased payouts after the tax cut. Because the rise in dividends is not compensated by an equally sized drop in share repurchases, the total payout also significantly increased after the tax cut, or in other words, retained earnings significantly decreased. When turning to corporate investment, we report a zero-elasticity with respect to dividend taxes. We show that this comes from the fact that treated firms do not raise enough equity to compensate 
for the contraction in retained earnings. Taken together, our findings suggest that (1) corporations do care about the taxes faced by its shareholders, (2) dividend taxes materially distort financial decisions of firms as they force corporations to retain too large a fraction of earnings, and (3) dividend tax cuts do not seem to boost investment but can alleviate agency problems.

More than 10 years after the second Corporate Taxation Reform was passed by the Swiss Parliament, tax-exempt dividends is still a prominent way for firms to return cash to their shareholders, and it is likely to remain the case for the years to come. Indeed, the latest figures for the year 2017 indicate that current reserves from capital contributions (required to pay taxexempt dividends) amount CHF1,955 Bio for all Swiss corporations, almost three times the Swiss GDP. Many large public firms replenished these reserves to record levels and will be able to pay years of tax-exempt dividends: 29 years of dividends for Credit Suisse, 19 years for Lonza, 14 years for Lafarge Holcim, and 13 years for UBS.

To conclude, it is interesting to notice that the fiscal reform investigated in this paper took place in a country with a particularly large financial sector. Following the Global Financial Crisis, Swiss banks, like their international peers, had to significantly increase their regulatory capital and it was costly for them to do so. Ironically, in Switzerland, we see in this paper that this cost was greatly mitigated by the fact that domestic banks were allowed to use this extra capital to pay tax-exempt dividends to their shareholders. While the question of whether reduced taxes can be an efficient way to reduce the burden of banking regulation is beyond the scope of this paper, it should warrant further investigation. 


\section{REFERENCES}

Aggarwal, R., Erel, I., Ferreira, M., Matos, P., 2011. Does governance travel around the world? Evidence from institutional investors. Journal of Financial Economics 100, 154-181.

Almeida, H., Campello, M., 2007. Financial constraints, asset tangibility, and corporate investment. Review of Financial Studies 20, 1429-1460.

Alstadsæter, A., Jacob, M., Michaely, R., 2017. Do dividend taxes affect corporate investment? Journal of Public Economics 151, 74-83.

Auerbach, A.J., 1979. Wealth maximization and the cost of capital. Quarterly Journal of Economics 93, 433-446.

Auerbach, A.J., 2002. Taxation and corporate financial policy. In: Auerbach AJ \& Feldstein M (eds.) Handbook of Public Economics. Elsevier, pp. 1251-1292.

Becker, B., Jacob, M., Jacob, M., 2013. Payout taxes and the allocation of investment. Journal of Financial Economics 107, 1-24.

Bernheim, B.D., 1991. Tax policy and the dividend puzzle. RAND Journal of Economics 22, 455-476.

Berzins, J., Bøhren, Ø., Stacescu, B., 2018. Shareholder conflicts and dividends. Review of Finance 22, 1807-1840.

Bradford, D.F., 1981. The incidence and allocation effects of a tax on corporate distributions. Journal of Public Economics 15, 1-22.

Brav, A., Graham, J.R., Harvey, C.R., Michaely, R., 2008. The effect of the May 2003 dividend tax cut on corporate dividend policy: Empirical and survey evidence. National Tax Journal 61, 381-396.

Brown, J.R., Liang, N., Weisbenner, S., 2007. Executive financial incentives and payout policy: Firm responses to the 2003 dividend tax cut. Journal of Finance 62, 1935-1965

Chetty, R., Saez, E., 2005. Dividend taxes and corporate behavior: Evidence from the 2003 dividend tax cut. Quarterly Journal of Economics 120, 791-833.

Chetty, R., Saez, E., 2010. Dividend and corporate taxation in an agency model of the firm. American Economic Journal: Economic Policy 2, 1-31.

Chung, D.Y., Isakov, D., Pérignon, C., 2007. Repurchasing shares on a second trading line. Review of Finance 11, 253-285.

Djankov, S., La Porta, R., Lopez-de-Silanes, F., Shleifer, A., 2008. The law and economics of self-dealing. Journal of Financial Economics 88, 430-465.

Doidge, C., Dyck, A., 2015. Taxes and corporate policies: Evidence from a quasi natural experiment. Journal of Finance 70, 45-89.

Doidge, C., Karolyi, G.A., Stulz, R.M., 2007. Why do countries matter so much for corporate governance? Journal of Financial Economics 86, 1-39.

Farre-Mensa, J., Michaely, R., Schmalz, M., 2014. Payout policy. Annual Review of Financial Economics 6, 75-134.

Feldstein, M.S., 1970. Corporate taxation and dividend behaviour. Review of Economic Studies 37, 57-72.

Foucault, T., Fresard, L., 2014. Learning from peers' stock prices and corporate investment. Journal of Financial Economics 111, 554-577.

Harberger, A.C., 1962. The incidence of the corporation income tax. Journal of Political Economy 70, 215-240.

Harberger, A.C., 1966. Efficiency effects of taxes on income from capital. In: Krzyzaniak M (ed.) Effects of Corporation Income Tax. Wayne State University Press, Detroit.

Hubbard, J., Michaely, R., 1997. Do investors ignore dividend taxation? A reexamination of the Citizens Utilities case. Journal of Financial and Quantitative Analysis 32, 117-135. 
Jacob, M., Michaely, R., 2017. Taxation and dividend policy: The muting effect of agency issues and shareholder conflicts. Review of Financial Studies 30, 3176-3222.

Jensen, M.C., 1986. Agency costs of free cash flow, corporate finance, and takeovers. American Economic Review 76, 323-329.

Jensen, M.C., Meckling, W.H., 1976. Theory of the firm: Managerial behavior, agency costs and ownership structure. Journal of Financial Economics 3, 305-360.

Julio, B., Ikenberry, D.L., 2004. Reappearing dividends. Journal of Applied Corporate Finance $16,89-100$.

King, M., 1974. Dividend behaviour and the theory of the firm. Economica 41, 25-34

La Porta, R., Lopez-de-Silanes, F., Shleifer, A., Vishny, R.W., 1998. Law and finance. Journal of Political Economy 106, 1113-1155.

La Porta, R., Lopez-de-Silanes, F., Shleifer, A., Vishny, R.W., 2000. Agency problems and dividend policies around the world. Journal of Finance 55, 1-33.

La Porta, R., Lopez de Silanes, F., Shleifer, A., Vishny, R.W., 1998. Law and finance. Journal of Political Economy 106, 1113-1155.

Myers, S., McConnell, J., Peterson, A., Roebuck, S., Soter, D., Stewart, S., Stern, J., 1998. Vanderbilt University roundtable on the capital structure puzzle. Journal of Applied Corporate Finance 11, 8-24.

Poterba, J., 2004. Taxation and corporate payout policy. American Economic Review 94, 171175.

Poterba, J.M., Summers, L.H., 1985. The economic effects of dividend taxation. In: Altman E \& Subrahmanyam M (eds.) Recent Advances in Corporate Finance. Dow Jones-Irwin Publishing, Homewood, IL, 227-284.

Von Eije, H., Megginson, W.L., 2008. Dividends and share repurchases in the European Union. Journal of Financial Economics 89, 347-374.

Yagan, D., 2015. Capital tax reform and the real economy: The effects of the 2003 dividend tax cut. American Economic Review 105, 3531-3563. 
Table 1

\begin{tabular}{|c|c|c|c|c|c|c|c|c|c|c|c|}
\hline & & & & \multicolumn{3}{|c|}{ Descriptive statistics } & & \multirow{2}{*}{\multicolumn{2}{|c|}{ Difference of means }} \\
\hline & \multirow{2}{*}{\multicolumn{3}{|c|}{$\underline{\text { All }}$}} & \multicolumn{3}{|c|}{ Control } & \multicolumn{3}{|c|}{ Treated } & & \\
\hline & & & & $\mathrm{Nb}$ of obs. & Mean & Median & $\mathrm{Nb}$ of obs. & Mean & Median & Difference & $\mathrm{p}$-value \\
\hline \multicolumn{12}{|l|}{ Dividends } \\
\hline Dividend yield & 210 & 2.03 & 2.00 & 114 & 1.99 & 2.00 & 96 & 2.07 & 2.00 & -0.08 & 0.77 \\
\hline Dividend pay-out & 210 & 34.78 & 30.50 & 114 & 33.97 & 28.50 & 96 & 35.73 & 33.00 & -1.76 & 0.70 \\
\hline Total pay-out & 210 & 36.31 & 32.00 & 114 & 35.58 & 30.50 & 96 & 37.19 & 34.50 & -1.61 & 0.72 \\
\hline$\%$ payers & 210 & 69.05 & 100.00 & 114 & 70.18 & 100.00 & 96 & 67.71 & 100.00 & 2.47 & 0.70 \\
\hline \multicolumn{12}{|l|}{ Firm characteristics } \\
\hline Cash \& equiv. & 210 & 1064770 & 97802 & 114 & 914321 & 77670 & 96 & 1243428 & 124042 & -329107 & 0.52 \\
\hline Total assets & 210 & 14100000 & 829002 & 114 & 9159766 & 708803 & 96 & 20100000 & 973600 & -10901275 & 0.18 \\
\hline$B V$ of equity & 210 & 2187605 & 348179 & 114 & 1832240 & 285760 & 96 & 2609600 & 464618 & -777359 & 0.40 \\
\hline MV of equity & 210 & 4643861 & 585414 & 114 & 4768620 & 405431 & 96 & 4495709 & 738332 & 272911 & 0.91 \\
\hline EBIT & 203 & 527648 & 40297 & 108 & 545545 & 37574 & 95 & 507303 & 61266 & 38241 & 0.88 \\
\hline Net Income & 210 & 312076 & 22028 & 114 & 345922 & 22169 & 96 & 271885 & 20960 & 74037 & 0.65 \\
\hline Age & 210 & 76.60 & 62.00 & 114 & 80.96 & 71.00 & 96 & 71.42 & 58.00 & 9.55 & 0.29 \\
\hline Cash\& equiv / total assets & 210 & 16.75 & 11.12 & 114 & 16.54 & 10.12 & 96 & 17.00 & 12.71 & -0.46 & 0.85 \\
\hline ROA & 203 & 2.37 & 3.79 & 108 & 2.32 & 3.77 & 95 & 2.43 & 3.79 & -0.11 & 0.95 \\
\hline ROE & 210 & 2.36 & 7.92 & 114 & 2.25 & 8.75 & 96 & 2.49 & 7.32 & -0.24 & 0.95 \\
\hline Leverage & 210 & 33.96 & 31.04 & 114 & 35.35 & 31.16 & 96 & 32.30 & 29.94 & 3.05 & 0.42 \\
\hline $\mathrm{Nb}$. Employees & 189 & 7551 & 1328 & 98 & 6849 & 1062 & 91 & 8306 & 1808 & -1457 & 0.59 \\
\hline Salaries & 199 & 674058 & 101308 & 110 & 606895 & 86548 & 89 & 757068 & 133700 & -150172 & 0.62 \\
\hline \multicolumn{12}{|l|}{ Investments } \\
\hline$\overline{\text { Capex }}$ & 202 & 134242 & 20940 & 108 & 121262 & 15021 & 94 & 149155 & 27712 & -27893 & 0.64 \\
\hline PPE & 204 & 820677 & 142951 & 108 & 763580 & 128550 & 96 & 884910 & 160036 & -121331 & 0.72 \\
\hline Capex / PPE & 198 & 29.25 & 15.02 & 106 & 30.72 & 13.70 & 92 & 27.55 & 17.37 & 3.17 & 0.66 \\
\hline \multicolumn{12}{|l|}{ Ownership \& Agency } \\
\hline$\overline{\text { Widely-held }}$ & 208 & 19.23 & 0.00 & 114 & 15.79 & 0.00 & 94 & 23.40 & 0.00 & -0.08 & 0.17 \\
\hline Blockholder & 208 & 80.77 & 100.00 & 114 & 84.21 & 100.00 & 94 & 76.60 & 100.00 & 0.08 & 0.17 \\
\hline Family & 208 & 50.96 & 100.00 & 114 & 52.63 & 100.00 & 94 & 48.94 & 0.00 & 0.04 & 0.60 \\
\hline Non-family blockholder & 208 & 29.81 & 0.00 & 114 & 31.58 & 0.00 & 94 & 27.66 & 0.00 & 0.04 & 0.54 \\
\hline Control-enhancing mechanism & 208 & 39.42 & 0.00 & 114 & 47.37 & 0.00 & 94 & 29.79 & 0.00 & 0.18 & 0.01 \\
\hline
\end{tabular}

This table presents descriptive statistics on corporate data for the year 2010 for all sample companies, control companies and treated companies. The last two columns describe differences of means between the treated and control group and the associated p-values. Dividends shows four variables related to dividend payments, Firm characteristics different accounting variables, Investments capex, PPE and their ratio and finally Ownership \& Agency gives a brief overview of the ownership structure and the use of controlenhancing mechanisms of companies. To be considered a blockholder, a family or non-family blockholder company, the largest shareholder must hold at least $10 \%$ of voting rights in a company otherwise the company is denoted as widely-held. Control-enhancing mechanisms denotes companies either having multiple share classes or voting right restrictions. 
Table 2

Treatment effect on payout

\begin{tabular}{|c|c|c|c|c|c|c|c|c|}
\hline & \multicolumn{2}{|c|}{ Dividend Yield } & \multicolumn{2}{|c|}{ Dividend Payout } & \multicolumn{2}{|c|}{ Total Payout } & \multicolumn{2}{|c|}{$\%$ Payers } \\
\hline & $(1)$ & (2) & (3) & (4) & $(5)$ & (6) & (7) & (8) \\
\hline Treated & $\begin{array}{c}0.665 * * * \\
(3.152)\end{array}$ & & $\begin{array}{c}9.221 * * * \\
(5.064)\end{array}$ & & $\begin{array}{c}9.889 * * * \\
(4.527)\end{array}$ & & $\begin{array}{c}6.725 * * \\
(2.607)\end{array}$ & \\
\hline Treated $(y-1)$ & & $\begin{array}{c}0.000 \\
(0.001)\end{array}$ & & $\begin{array}{c}0.485 \\
(0.134)\end{array}$ & & $\begin{array}{c}-1.406 \\
(-0.418)\end{array}$ & & $\begin{array}{l}-2.915 \\
(-0.845)\end{array}$ \\
\hline Treated (y0) & & $\begin{array}{c}0.473 * * \\
(2.131)\end{array}$ & & $\begin{array}{l}6.261 * \\
(1.777)\end{array}$ & & $\begin{array}{l}6.336^{*} \\
(1.869)\end{array}$ & & $\begin{array}{l}7.118^{*} \\
(1.704)\end{array}$ \\
\hline Treated $(y+1)$ & & $\begin{array}{c}0.913 * * \\
(2.296)\end{array}$ & & $\begin{array}{c}7.256^{* *} \\
(2.143)\end{array}$ & & $\begin{array}{c}7.448 \\
(1.686)\end{array}$ & & $\begin{array}{l}7.574^{*} \\
(1.908)\end{array}$ \\
\hline Treated $(\mathrm{y} 2+)$ & & $\begin{array}{c}0.650 * * \\
(2.639)\end{array}$ & & $\begin{array}{c}11.267 * * * \\
(4.328)\end{array}$ & & $\begin{array}{c}11.449 * * * \\
(4.382)\end{array}$ & & $\begin{array}{c}4.919 \\
(1.590)\end{array}$ \\
\hline Size & $\begin{array}{c}-0.116 \\
(-0.731)\end{array}$ & $\begin{array}{c}-0.115 \\
(-0.710)\end{array}$ & $\begin{array}{c}2.192 \\
(0.823)\end{array}$ & $\begin{array}{c}2.287 \\
(0.861)\end{array}$ & $\begin{array}{c}2.554 \\
(0.850)\end{array}$ & $\begin{array}{c}2.657 \\
(0.885)\end{array}$ & $\begin{array}{c}-0.010 \\
(-0.003)\end{array}$ & $\begin{array}{c}-0.047 \\
(-0.013)\end{array}$ \\
\hline Age & $\begin{array}{c}0.134 \\
(0.246)\end{array}$ & $\begin{array}{c}0.128 \\
(0.232)\end{array}$ & $\begin{array}{c}5.007 \\
(0.717)\end{array}$ & $\begin{array}{c}4.582 \\
(0.665)\end{array}$ & $\begin{array}{c}4.667 \\
(0.632)\end{array}$ & $\begin{array}{c}4.226 \\
(0.578)\end{array}$ & $\begin{array}{l}17.111 \\
(1.327)\end{array}$ & $\begin{array}{l}17.304 \\
(1.338)\end{array}$ \\
\hline Constant & $\begin{array}{c}3.210 \\
(1.206)\end{array}$ & $\begin{array}{c}3.227 \\
(1.201)\end{array}$ & $\begin{array}{l}-12.270 \\
(-0.272)\end{array}$ & $\begin{array}{l}-12.855 \\
(-0.287)\end{array}$ & $\begin{array}{l}-13.535 \\
(-0.258)\end{array}$ & $\begin{array}{l}-13.951 \\
(-0.268)\end{array}$ & $\begin{array}{c}6.610 \\
(0.090)\end{array}$ & $\begin{array}{c}7.191 \\
(0.097)\end{array}$ \\
\hline Observations & 1,859 & 1,859 & 1,859 & 1,859 & 1,859 & 1,859 & 1,859 & 1,859 \\
\hline R-squared & 0.620 & 0.620 & 0.575 & 0.576 & 0.564 & 0.565 & 0.688 & 0.688 \\
\hline Firm FE & YES & YES & YES & YES & YES & YES & YES & YES \\
\hline Year FE & YES & YES & YES & YES & YES & YES & YES & YES \\
\hline
\end{tabular}

This table presents results of a difference-in-differences OLS regression over the period 2007-2015. The explained variable is, alternatively, the dividend yield (DPS over stock price), dividend payout (DPS over EPS), total payout (dividends + repurchases over earnings) and the \% of dividend payers. Treated denotes companies that can pay tax exempt dividends. (y-1) denotes the treatment effect one year before the tax cut, (y0) the year of the tax cut, $(\mathrm{y}+1)$ the year after the tax cut and $(\mathrm{y} 2+)$ two and more years after the tax cut. Size is the natural logarithm of total assets and Age the natural logarithm of company age. All specifications use industry clustered robust standard errors. $*, * *, * * *$ denote significance at the $10 \%, 5 \%$ and $1 \%$ level respectively. 
Table 3

Treatment effect on payout without late arrivals

\begin{tabular}{|c|c|c|c|c|c|c|c|c|}
\hline & \multicolumn{2}{|c|}{ Dividend Yield } & \multicolumn{2}{|c|}{ Dividend Payout } & \multicolumn{2}{|c|}{ Total Payout } & \multicolumn{2}{|c|}{$\%$ Payers } \\
\hline & $(1)$ & (2) & (3) & $(4)$ & $(5)$ & $(6)$ & (7) & $(8)$ \\
\hline Treated & $\begin{array}{c}0.681 * * * \\
(2.983)\end{array}$ & & $\begin{array}{c}8.958 * * * \\
(3.603)\end{array}$ & & $\begin{array}{c}9.492 * * * \\
(3.781)\end{array}$ & & $\begin{array}{c}8.184 * * \\
(2.463)\end{array}$ & \\
\hline Treated (y-1) & & $\begin{array}{c}0.004 \\
(0.024)\end{array}$ & & $\begin{array}{c}0.572 \\
(0.158)\end{array}$ & & $\begin{array}{c}-1.329 \\
(-0.394)\end{array}$ & & $\begin{array}{c}-2.485 \\
(-0.724)\end{array}$ \\
\hline Treated (y0) & & $\begin{array}{c}0.478 * * \\
(2.155)\end{array}$ & & $\begin{array}{l}6.333^{*} \\
(1.787)\end{array}$ & & $\begin{array}{l}6.405^{*} \\
(1.882)\end{array}$ & & $\begin{array}{c}7.504^{*} \\
(1.760)\end{array}$ \\
\hline Treated $(y+1)$ & & $\begin{array}{c}0.995 * * \\
(2.227)\end{array}$ & & $\begin{array}{c}6.831 \\
(1.545)\end{array}$ & & $\begin{array}{c}6.676 \\
(1.343)\end{array}$ & & $\begin{array}{c}6.884 \\
(1.549)\end{array}$ \\
\hline Treated $(\mathrm{y} 2+)$ & & $\begin{array}{c}0.686^{* *} \\
(2.400)\end{array}$ & & $\begin{array}{c}11.595^{* * *} * \\
\quad(3.260)\end{array}$ & & $\begin{array}{c}11.660 * * * \\
(3.601)\end{array}$ & & $\begin{array}{l}7.764^{*} \\
(1.723)\end{array}$ \\
\hline Size & $\begin{array}{c}-0.181 \\
(-0.988)\end{array}$ & $\begin{array}{c}-0.180 \\
(-0.955)\end{array}$ & $\begin{array}{c}1.298 \\
(0.396)\end{array}$ & $\begin{array}{c}1.451 \\
(0.444)\end{array}$ & $\begin{array}{c}2.210 \\
(0.597)\end{array}$ & $\begin{array}{c}2.373 \\
(0.642)\end{array}$ & $\begin{array}{c}-0.378 \\
(-0.091)\end{array}$ & $\begin{array}{c}-0.353 \\
(-0.085)\end{array}$ \\
\hline Age & $\begin{array}{c}-0.071 \\
(-0.121)\end{array}$ & $\begin{array}{c}-0.094 \\
(-0.157)\end{array}$ & $\begin{array}{c}4.663 \\
(0.675)\end{array}$ & $\begin{array}{c}3.682 \\
(0.545)\end{array}$ & $\begin{array}{c}5.242 \\
(0.666)\end{array}$ & $\begin{array}{c}4.232 \\
(0.544)\end{array}$ & $\begin{array}{c}21.160 * * * \\
\quad(3.020)\end{array}$ & $\begin{array}{c}21.060 * * * \\
(2.941)\end{array}$ \\
\hline Constant & $\begin{array}{c}4.959 \\
(1.651)\end{array}$ & $\begin{array}{c}5.039 \\
(1.667)\end{array}$ & $\begin{array}{c}2.755 \\
(0.054)\end{array}$ & $\begin{array}{c}2.985 \\
(0.058)\end{array}$ & $\begin{array}{c}-9.736 \\
(-0.157)\end{array}$ & $\begin{array}{c}-9.292 \\
(-0.150)\end{array}$ & $\begin{array}{c}-7.000 \\
(-0.108)\end{array}$ & $\begin{array}{c}-6.753 \\
(-0.104)\end{array}$ \\
\hline Observations & 1,681 & 1,681 & 1,681 & 1,681 & 1,681 & 1,681 & 1,681 & 1,681 \\
\hline R-squared & 0.623 & 0.623 & 0.575 & 0.575 & 0.564 & 0.564 & 0.713 & 0.713 \\
\hline Firm FE & YES & YES & YES & YES & YES & YES & YES & YES \\
\hline Year FE & YES & YES & YES & YES & YES & YES & YES & YES \\
\hline
\end{tabular}

This table presents results of a difference-in-differences OLS regression over the period 2007-2015 discarding companies which were treated after the shock. The explained variable is, alternatively, the dividend yield (DPS over stock price), dividend payout (DPS over EPS), total payout (dividends + repurchases over earnings) and the $\%$ of dividend payers. Treated denotes companies that can pay tax exempt dividends. (y-1) denotes the treatment effect one year before the tax cut, $(\mathrm{y} 0)$ the year of the tax cut, $(\mathrm{y}+1)$ the year after the tax cut and $(\mathrm{y} 2+)$ two and more years after the tax cut. Size is the natural logarithm of total assets and Age the natural logarithm of company age. All specifications use industry clustered robust standard errors. *, **,*** denote significance at the $10 \%$, $5 \%$ and $1 \%$ level respectively. 
Table 4

Treatment effect on payout over a restricted period and with late arrivals

\begin{tabular}{|c|c|c|c|c|c|c|c|c|}
\hline & \multicolumn{2}{|c|}{ Dividend Yield } & \multicolumn{2}{|c|}{ Dividend Payout } & \multicolumn{2}{|c|}{ Total Payout } & \multicolumn{2}{|c|}{ \% Payers } \\
\hline & $(1)$ & $(2)$ & (3) & $(4)$ & $(5)$ & (6) & (7) & $(8)$ \\
\hline Treated & $\begin{array}{l}0.457^{*} \\
(2.031)\end{array}$ & & $\begin{array}{c}6.642 * * \\
(2.110)\end{array}$ & & $\begin{array}{c}7.328 * * \\
(2.414)\end{array}$ & & $\begin{array}{l}7.868^{*} \\
(1.861)\end{array}$ & \\
\hline Treated vs. Late & & $\begin{array}{c}0.608 * * \\
(2.185)\end{array}$ & & $\begin{array}{c}11.594 * * * \\
(3.143)\end{array}$ & & $\begin{array}{c}11.182 * * * \\
(3.582)\end{array}$ & & $\begin{array}{l}11.189 * \\
(1.847)\end{array}$ \\
\hline Size & $\begin{array}{c}-0.099 \\
(-0.657)\end{array}$ & $\begin{array}{c}-0.236 \\
(-1.084)\end{array}$ & $\begin{array}{c}0.370 \\
(0.094)\end{array}$ & $\begin{array}{c}-0.270 \\
(-0.057)\end{array}$ & $\begin{array}{c}2.624 \\
(0.608)\end{array}$ & $\begin{array}{c}2.878 \\
(0.567)\end{array}$ & $\begin{array}{c}3.064 \\
(0.851)\end{array}$ & $\begin{array}{c}0.632 \\
(0.120)\end{array}$ \\
\hline Age & $\begin{array}{c}0.135 \\
(0.137)\end{array}$ & $\begin{array}{c}0.871 \\
(0.858)\end{array}$ & $\begin{array}{l}-15.612 \\
(-0.865)\end{array}$ & $\begin{array}{c}-3.296 \\
(-0.179)\end{array}$ & $\begin{array}{l}-19.413 \\
(-0.963)\end{array}$ & $\begin{array}{c}-9.990 \\
(-0.470)\end{array}$ & $\begin{array}{l}14.768 \\
(0.708)\end{array}$ & $\begin{array}{c}31.982 * * \\
(2.068)\end{array}$ \\
\hline Constant & $\begin{array}{c}2.834 \\
(0.691)\end{array}$ & $\begin{array}{c}1.761 \\
(0.389)\end{array}$ & $\begin{array}{l}90.206 \\
(1.136)\end{array}$ & $\begin{array}{l}43.734 \\
(0.470)\end{array}$ & $\begin{array}{r}76.334 \\
(0.886)\end{array}$ & $\begin{array}{l}29.024 \\
(0.295)\end{array}$ & $\begin{array}{l}-31.126 \\
(-0.341)\end{array}$ & $\begin{array}{l}-67.345 \\
(-0.692)\end{array}$ \\
\hline Observations & 1,049 & 675 & 1,049 & 675 & 1,049 & 675 & 1,049 & 675 \\
\hline R-squared & 0.702 & 0.711 & 0.603 & 0.602 & 0.580 & 0.576 & 0.772 & 0.746 \\
\hline Firm FE & YES & YES & YES & YES & YES & YES & YES & YES \\
\hline Year FE & YES & YES & YES & YES & YES & YES & YES & YES \\
\hline
\end{tabular}

This table presents results of a difference-in-differences OLS regression over the period 2007-2015 comparing the treatment effect over a shorter period between 2007 and 2011 (columns 1, 3 and 5) and treated firms with respect to late treated firms only (columns 2, 4 and 6). The explained variable is, alternatively, the dividend yield (DPS over stock price), dividend payout (DPS over EPS), total payout (dividends + repurchases over earnings) and the $\%$ of dividend payers. Treated denotes companies that can pay tax exempt dividends. Size is the natural logarithm of total assets and Age the natural logarithm of company age. All specifications use industry clustered robust standard errors. $*, * *, * * *$ denote significance at the $10 \%, 5 \%$ and $1 \%$ level respectively. 
Table 5

Treatment effect on payout after removing financial companies

\begin{tabular}{|c|c|c|c|c|c|c|c|c|}
\hline & \multicolumn{2}{|c|}{ Dividend Yield } & \multicolumn{2}{|c|}{ Dividend Payout } & \multicolumn{2}{|c|}{ Total Payout } & \multicolumn{2}{|c|}{$\%$ Payers } \\
\hline & $(1)$ & $(2)$ & (3) & (4) & $(5)$ & $(6)$ & (7) & $(8)$ \\
\hline Treated & $\begin{array}{c}0.690 * * * \\
(3.014)\end{array}$ & & $\begin{array}{c}8.796 * * * \\
(3.563)\end{array}$ & & $\begin{array}{c}8.880 * * * \\
(3.100)\end{array}$ & & $\begin{array}{l}5.658^{*} \\
(1.789)\end{array}$ & \\
\hline Treated (y-1) & & $\begin{array}{c}0.029 \\
(0.131)\end{array}$ & & $\begin{array}{c}1.079 \\
(0.247)\end{array}$ & & $\begin{array}{c}-1.371 \\
(-0.321)\end{array}$ & & $\begin{array}{c}0.196 \\
(0.046)\end{array}$ \\
\hline Treated (y0) & & $\begin{array}{c}0.529 * * \\
(2.246)\end{array}$ & & $\begin{array}{l}7.292^{*} \\
(1.840)\end{array}$ & & $\begin{array}{c}6.059 \\
(1.414)\end{array}$ & & $\begin{array}{c}10.795^{*} \\
(1.953)\end{array}$ \\
\hline Treated $(\mathrm{y}+1)$ & & $\begin{array}{c}0.771 \\
(1.693)\end{array}$ & & $\begin{array}{c}4.607 \\
(1.083)\end{array}$ & & $\begin{array}{c}4.260 \\
(0.753)\end{array}$ & & $\begin{array}{c}5.276 \\
(1.079)\end{array}$ \\
\hline Treated $(\mathrm{y} 2+)$ & & $\begin{array}{c}0.736 * * * \\
(2.880)\end{array}$ & & $\begin{array}{c}11.365^{* * *} * \\
(3.225)\end{array}$ & & $\begin{array}{c}10.979 * * * \\
(3.072)\end{array}$ & & $\begin{array}{c}3.917 \\
(1.055)\end{array}$ \\
\hline Size & $\begin{array}{l}0.101^{*} \\
(1.851)\end{array}$ & $\begin{array}{l}0.104 * \\
(1.866)\end{array}$ & $\begin{array}{c}5.743 * * * \\
(3.299)\end{array}$ & $\begin{array}{c}5.824 * * * \\
(3.395)\end{array}$ & $\begin{array}{c}6.402 * * * \\
(3.050)\end{array}$ & $\begin{array}{c}6.508 * * * \\
(3.143)\end{array}$ & $\begin{array}{c}4.136 \\
(1.247)\end{array}$ & $\begin{array}{c}4.018 \\
(1.189)\end{array}$ \\
\hline Age & $\begin{array}{c}0.392 \\
(0.659)\end{array}$ & $\begin{array}{c}0.378 \\
(0.624)\end{array}$ & $\begin{array}{c}7.436 \\
(0.959)\end{array}$ & $\begin{array}{c}7.008 \\
(0.912)\end{array}$ & $\begin{array}{c}7.324 \\
(0.817)\end{array}$ & $\begin{array}{c}6.751 \\
(0.759)\end{array}$ & $\begin{array}{c}30.931 * * * \\
(2.966)\end{array}$ & $\begin{array}{c}31.495 * * * \\
(2.939)\end{array}$ \\
\hline Constant & $\begin{array}{c}-1.154 \\
(-0.505)\end{array}$ & $\begin{array}{c}-1.162 \\
(-0.500)\end{array}$ & $\begin{array}{l}-70.564 \\
(-1.575)\end{array}$ & $\begin{array}{l}-71.181 \\
(-1.618)\end{array}$ & $\begin{array}{l}-75.460 \\
(-1.412)\end{array}$ & $\begin{array}{l}-75.607 \\
(-1.447)\end{array}$ & $\begin{array}{c}-106.894 * \\
(-1.712)\end{array}$ & $\begin{array}{c}-106.732 \\
(-1.695)\end{array}$ \\
\hline Observations & 1,338 & 1,338 & 1,338 & 1,338 & 1,338 & 1,338 & 1,338 & 1,338 \\
\hline R-squared & 0.547 & 0.547 & 0.550 & 0.551 & 0.549 & 0.550 & 0.680 & 0.680 \\
\hline Firm FE & YES & YES & YES & YES & YES & YES & YES & YES \\
\hline Year FE & YES & YES & YES & YES & YES & YES & YES & YES \\
\hline
\end{tabular}

This table presents results of a difference-in-differences OLS regression over the period 2007-2015 excluding all financial companies. The explained variable is, alternatively, the dividend yield (DPS over stock price), dividend payout (DPS over EPS), total payout (dividends + repurchases over earnings) and the \% of dividend payers. Treated denotes companies that can pay tax exempt dividends. $(\mathrm{y}-1)$ denotes the treatment effect one year before the tax cut, $(\mathrm{y} 0)$ the year of the tax cut, $(\mathrm{y}+1)$ the year after the tax cut and $(\mathrm{y} 2+)$ two and more years after the tax cut. Size is the natural logarithm of total assets and Age the natural logarithm of company age. All specifications use industry clustered robust standard errors. $*, * *, * *$ denote significance at the $10 \%, 5 \%$ and $1 \%$ level respectively. 
Table 6

Treatment effect on corporate investment

\begin{tabular}{|c|c|c|c|c|c|c|c|c|}
\hline & \multicolumn{4}{|c|}{$\ln ($ capex $)$} & \multicolumn{4}{|c|}{ capex / PPE } \\
\hline & (1) & (2) & (3) & (4) & (5) & (6) & (7) & (8) \\
\hline \multirow[t]{2}{*}{ Treated } & 0.084 & & & & -2.120 & & & \\
\hline & $(0.737)$ & & & & $(-0.881)$ & & & \\
\hline \multirow[t]{2}{*}{ Treated w/out late } & & 0.093 & & & & -1.312 & & \\
\hline & & $(0.676)$ & & & & $(-0.570)$ & & \\
\hline \multirow[t]{2}{*}{ Treated } & & & 0.204 & & & & 0.903 & \\
\hline & & & (1.439) & & & & $(0.233)$ & \\
\hline \multirow[t]{2}{*}{ Treated vs. Late } & & & & 0.135 & & & & 0.249 \\
\hline & & & & $(0.792)$ & & & & $(0.051)$ \\
\hline \multirow[t]{2}{*}{ Size } & $0.951 * * *$ & $0.999 * * *$ & $0.808 * * *$ & $0.789 * * *$ & -6.467 & -2.497 & -5.743 & -7.520 \\
\hline & $(4.748)$ & (4.497) & $(6.023)$ & $(6.200)$ & $(-1.440)$ & $(-0.808)$ & $(-0.964)$ & $(-1.184)$ \\
\hline \multirow[t]{2}{*}{ Age } & $-0.518^{* *}$ & $-0.616^{*}$ & -0.457 & -0.533 & $-6.600^{*}$ & $-11.056^{*}$ & $-12.996^{*}$ & $-13.856^{*}$ \\
\hline & $(-2.105)$ & $(-1.980)$ & $(-1.255)$ & $(-1.436)$ & $(-2.023)$ & $(-1.941)$ & $(-1.789)$ & $(-1.785)$ \\
\hline \multirow[t]{2}{*}{ Constant } & -0.992 & -1.179 & 0.443 & 0.968 & $134.331^{* *}$ & $99.402 *$ & 145.481 & $172.145^{*}$ \\
\hline & $(-0.346)$ & $(-0.381)$ & $(0.174)$ & $(0.429)$ & $(2.111)$ & $(1.940)$ & $(1.670)$ & (1.993) \\
\hline Observations & 1,396 & 1,273 & 810 & 535 & 1,326 & 1,204 & 755 & 516 \\
\hline R-squared & 0.919 & 0.921 & 0.930 & 0.931 & 0.482 & 0.519 & 0.596 & 0.625 \\
\hline Firm FE & YES & YES & YES & YES & YES & YES & YES & YES \\
\hline Year FE & YES & YES & YES & YES & YES & YES & YES & YES \\
\hline
\end{tabular}

This table presents results of a difference-in-differences OLS regression over the period 2007-2015 comparing treated firms to control firms (columns 1 and 5), treated firms to a control group discarding late arrivals (columns 2 and 6), the treatment effect over a shorter period between 2007 and 2011 (columns 3 and 7) and treated firms to late treated firms only (columns 4 and 8). The explained variable is, alternatively, the natural logarithm of capex and the ratio of capex over lagged PPE. This ratio is winsorized at the 1st and 99th percentiles. Treated denotes companies that can pay tax exempt dividends. Size is the natural logarithm of total assets and Age the natural logarithm of company age. All specifications use industry clustered robust standard errors. *, **, *** denote significance at the $10 \%, 5 \%$ and $1 \%$ level respectively. 
Table 7

Treatment effect on financing sources

\begin{tabular}{|c|c|c|c|c|c|c|c|c|c|c|c|c|}
\hline & \multicolumn{4}{|c|}{$\ln$ (BV equity) } & \multicolumn{4}{|c|}{ BV equity / total assets } & \multicolumn{4}{|c|}{ Cash \& equiv / total assets } \\
\hline & (1) & (2) & (3) & (4) & (5) & (6) & (7) & (8) & (9) & (10) & (11) & (12) \\
\hline Treated & $\begin{array}{c}0.069 \\
(0.779)\end{array}$ & & & & $\begin{array}{c}2.685 \\
(1.136)\end{array}$ & & & & $\begin{array}{c}0.298 \\
(0.243)\end{array}$ & & & \\
\hline Treated w/out late & & $\begin{array}{c}0.085 \\
(0.782)\end{array}$ & & & & $\begin{array}{c}2.683 \\
(1.134)\end{array}$ & & & & $\begin{array}{l}0.557 \\
(0.428)\end{array}$ & & \\
\hline Treated & & & $\begin{array}{c}0.024 \\
(0.198)\end{array}$ & & & & $\begin{array}{c}2.359 \\
(0.846)\end{array}$ & & & & $\begin{array}{l}1.780 \\
(0.913)\end{array}$ & \\
\hline Treated vs. Late & & & & $\begin{array}{c}0.087 \\
(0.468)\end{array}$ & & & & $\begin{array}{c}2.793 \\
(0.912)\end{array}$ & & & & $\begin{array}{l}-0.198 \\
(-0.090)\end{array}$ \\
\hline Size & $\begin{array}{c}0.729 * * * \\
(3.583)\end{array}$ & $\begin{array}{c}0.725 * * * \\
(3.133)\end{array}$ & $\begin{array}{r}0.348^{* *} \\
(2.149)\end{array}$ & $\begin{array}{l}0.401^{*} \\
(2.030)\end{array}$ & $\begin{array}{c}5.039 * * \\
(2.491)\end{array}$ & $\begin{array}{r}5.014 * * \\
(2.281)\end{array}$ & $\begin{array}{c}2.466 \\
(0.762)\end{array}$ & $\begin{array}{c}0.692 \\
(0.281)\end{array}$ & $\begin{array}{l}-1.122 \\
(-0.640)\end{array}$ & $\begin{array}{l}-0.131 \\
(-0.078)\end{array}$ & $\begin{array}{l}-0.397 \\
(-0.111)\end{array}$ & $\begin{array}{l}-4.272 * * * \\
(-5.487)\end{array}$ \\
\hline Age & $\begin{array}{c}-0.135 \\
(-0.487)\end{array}$ & $\begin{array}{c}-0.155 \\
(-0.505)\end{array}$ & $\begin{array}{c}0.243 \\
(0.720)\end{array}$ & $\begin{array}{c}0.244 \\
(0.618)\end{array}$ & $\begin{array}{c}-4.434 \\
(-1.010)\end{array}$ & $\begin{array}{l}-4.472 \\
(-0.916)\end{array}$ & $\begin{array}{c}-2.004 \\
(-0.321)\end{array}$ & $\begin{array}{c}2.820 \\
(0.477)\end{array}$ & $\begin{array}{l}-3.281 \\
(-0.905)\end{array}$ & $\begin{array}{l}-3.972 \\
(-0.973)\end{array}$ & $\begin{array}{l}-1.847 \\
(-0.392)\end{array}$ & $\begin{array}{l}-0.432 \\
(-0.088)\end{array}$ \\
\hline Constant & $\begin{array}{c}3.381 \\
(1.276)\end{array}$ & $\begin{array}{c}3.494 \\
(1.174)\end{array}$ & $\begin{array}{l}6.922 * * \\
(2.727)\end{array}$ & $\begin{array}{l}6.158^{*} \\
(2.014)\end{array}$ & $\begin{array}{c}0.810 \\
(0.029)\end{array}$ & $\begin{array}{c}1.246 \\
(0.041)\end{array}$ & $\begin{array}{l}27.476 \\
(0.778)\end{array}$ & $\begin{array}{l}30.333 \\
(0.988)\end{array}$ & $\begin{array}{l}47.309 \\
(1.677)\end{array}$ & $\begin{array}{l}36.603 \\
(1.444)\end{array}$ & $\begin{array}{l}30.838 \\
(0.695)\end{array}$ & $\begin{array}{l}78.973^{* * * *} \\
(5.510)\end{array}$ \\
\hline Observations & 1,396 & 1,275 & 811 & 536 & 1,408 & 1,285 & 814 & 536 & 1,406 & 1,283 & 812 & 536 \\
\hline R-squared & 0.952 & 0.951 & 0.963 & 0.943 & 0.778 & 0.781 & 0.830 & 0.860 & 0.786 & 0.787 & 0.832 & 0.866 \\
\hline Firm FE & YES & YES & YES & YES & YES & YES & YES & YES & YES & YES & YES & YES \\
\hline Year FE & YES & YES & YES & YES & YES & YES & YES & YES & YES & YES & YES & YES \\
\hline
\end{tabular}

This table presents results of a difference-in differences OLS regression over the period 2007-2015 comparing treated firms to control firms (columns 1, 5 and 9), treated firms to a control group discarding late arrivals (columns 2, 6 and 10), the treatment effect over a shorter period between 2006 and 2010 (columns 3, 7 and 11) and treated firms to late treated firms only (columns 4, 8 and 12). The explained variable is, alternatively, the natural logarithm of the book value of equity, the ratio of book value of equity over total assets, and cash \& equivalents over total assets. Treated denotes companies that can pay tax exempt dividends. Size is the natural logarithm of total assets and Age the natural logarithm of company age. All specifications use industry clustered robust standard errors. *, $* *, * * *$ denote significance at the $10 \%, 5 \%$ and $1 \%$ level respectively. 
Table 8

Agency costs

\begin{tabular}{|c|c|c|c|c|c|c|c|c|}
\hline & & & Dividen & Pay-out & Total & y-out & $\% \mathrm{p}$ & ers \\
\hline & $(1)$ & (2) & (3) & (4) & $(5)$ & (6) & $(7)$ & $(8)$ \\
\hline Treated (widely-held) & $\begin{array}{c}0.970^{* *} \\
(2.487)\end{array}$ & & $\begin{array}{c}12.686^{* * * *} \\
(3.489)\end{array}$ & & $\begin{array}{c}13.209 * * * \\
(3.176)\end{array}$ & & $\begin{array}{c}14.517 * * * \\
(3.161)\end{array}$ & \\
\hline Treated (widely-held with CEM) & & $\begin{array}{c}0.913 * * * \\
(8.224)\end{array}$ & & $\begin{array}{c}16.245 * * * \\
(8.791)\end{array}$ & & $\begin{array}{c}18.324 * * * \\
(9.660)\end{array}$ & & $\begin{array}{c}27.275 * * * \\
(8.240)\end{array}$ \\
\hline Treated widely-held w/out CEM) & & $\begin{array}{c}1.017 * * \\
(2.417)\end{array}$ & & $\begin{array}{c}13.002 * * * \\
(3.261)\end{array}$ & & $\begin{array}{c}13.589 * * * \\
(2.947)\end{array}$ & & $\begin{array}{c}14.488 * * * \\
(2.943)\end{array}$ \\
\hline Treated (blockholder) & $\begin{array}{c}0.583^{* *} \\
(2.591)\end{array}$ & & $\begin{array}{c}8.010^{* * * *} \\
(4.425)\end{array}$ & & $\begin{array}{c}8.714 * * * \\
(3.542)\end{array}$ & & $\begin{array}{l}4.138^{*} \\
(1.794)\end{array}$ & \\
\hline Treated (blockholder with CEM) & & $\begin{array}{c}0.223 \\
(0.629)\end{array}$ & & $\begin{array}{c}4.093 \\
(0.923)\end{array}$ & & $\begin{array}{c}3.690 \\
(0.629)\end{array}$ & & $\begin{array}{c}-0.410 \\
(-0.063)\end{array}$ \\
\hline Treated (blockholder w/out CEM) & & $\begin{array}{r}0.793 * * \\
(2.440)\end{array}$ & & $\begin{array}{c}10.277 * * * \\
(3.448)\end{array}$ & & $\begin{array}{c}11.619 * * * \\
(3.551)\end{array}$ & & $\begin{array}{l}6.727^{*} \\
(1.950)\end{array}$ \\
\hline Size & $\begin{array}{c}-0.163 \\
(-1.040)\end{array}$ & $\begin{array}{c}-0.132 \\
(-0.906)\end{array}$ & $\begin{array}{c}0.346 \\
(0.150)\end{array}$ & $\begin{array}{c}0.675 \\
(0.309)\end{array}$ & $\begin{array}{c}0.717 \\
(0.254)\end{array}$ & $\begin{array}{c}1.139 \\
(0.419)\end{array}$ & $\begin{array}{c}-2.574 \\
(-0.857)\end{array}$ & $\begin{array}{c}-2.198 \\
(-0.758)\end{array}$ \\
\hline Age & $\begin{array}{c}0.119 \\
(0.211)\end{array}$ & $\begin{array}{c}0.062 \\
(0.110)\end{array}$ & $\begin{array}{c}5.837 \\
(0.839)\end{array}$ & $\begin{array}{c}5.254 \\
(0.792)\end{array}$ & $\begin{array}{c}5.422 \\
(0.727)\end{array}$ & $\begin{array}{c}4.680 \\
(0.644)\end{array}$ & $\begin{array}{l}16.311 \\
(1.263)\end{array}$ & $\begin{array}{l}15.725 \\
(1.262)\end{array}$ \\
\hline Constant & $\begin{array}{c}3.953 \\
(1.427)\end{array}$ & $\begin{array}{c}3.759 \\
(1.394)\end{array}$ & $\begin{array}{l}10.346 \\
(0.250)\end{array}$ & $\begin{array}{c}8.101 \\
(0.206)\end{array}$ & $\begin{array}{c}9.315 \\
(0.185)\end{array}$ & $\begin{array}{c}6.418 \\
(0.135)\end{array}$ & $\begin{array}{l}46.359 \\
(0.678)\end{array}$ & $\begin{array}{l}43.486 \\
(0.654)\end{array}$ \\
\hline Observations & 1,823 & 1,823 & 1,823 & 1,823 & 1,823 & 1,823 & 1,823 & 1,823 \\
\hline R-squared & 0.617 & 0.619 & 0.576 & 0.577 & 0.565 & 0.566 & 0.688 & 0.689 \\
\hline Firm FE & YES & YES & YES & YES & YES & YES & YES & YES \\
\hline Year FE & YES & YES & YES & YES & YES & YES & YES & YES \\
\hline
\end{tabular}

This table presents results of a difference-in-differences OLS regression over the period 2007-2015 for treated companies with a blockholder or being widely-held (columns 1,3,5 and 7) and depending on the presence of control-enhancing mechanisms in either group (columns 2, 4, 6 and 8). The explained variable is, alternatively, the dividend yield (DPS over stock price), dividend payout (DPS over EPS), total payout (dividends + repurchases over earnings) and the \% of dividend payers. Size is the natural logarithm of total assets and Age the natural logarithm of company age. All specifications use industry clustered robust standard errors. ${ }^{*},{ }^{* *},{ }^{* * *}$ denote significance at the $10 \%, 5 \%$ and $1 \%$ level respectively. 
Figure 1

Evolution of payout in Switzerland

Panel A: Evolution of aggregate dividends and aggregate share repurchases

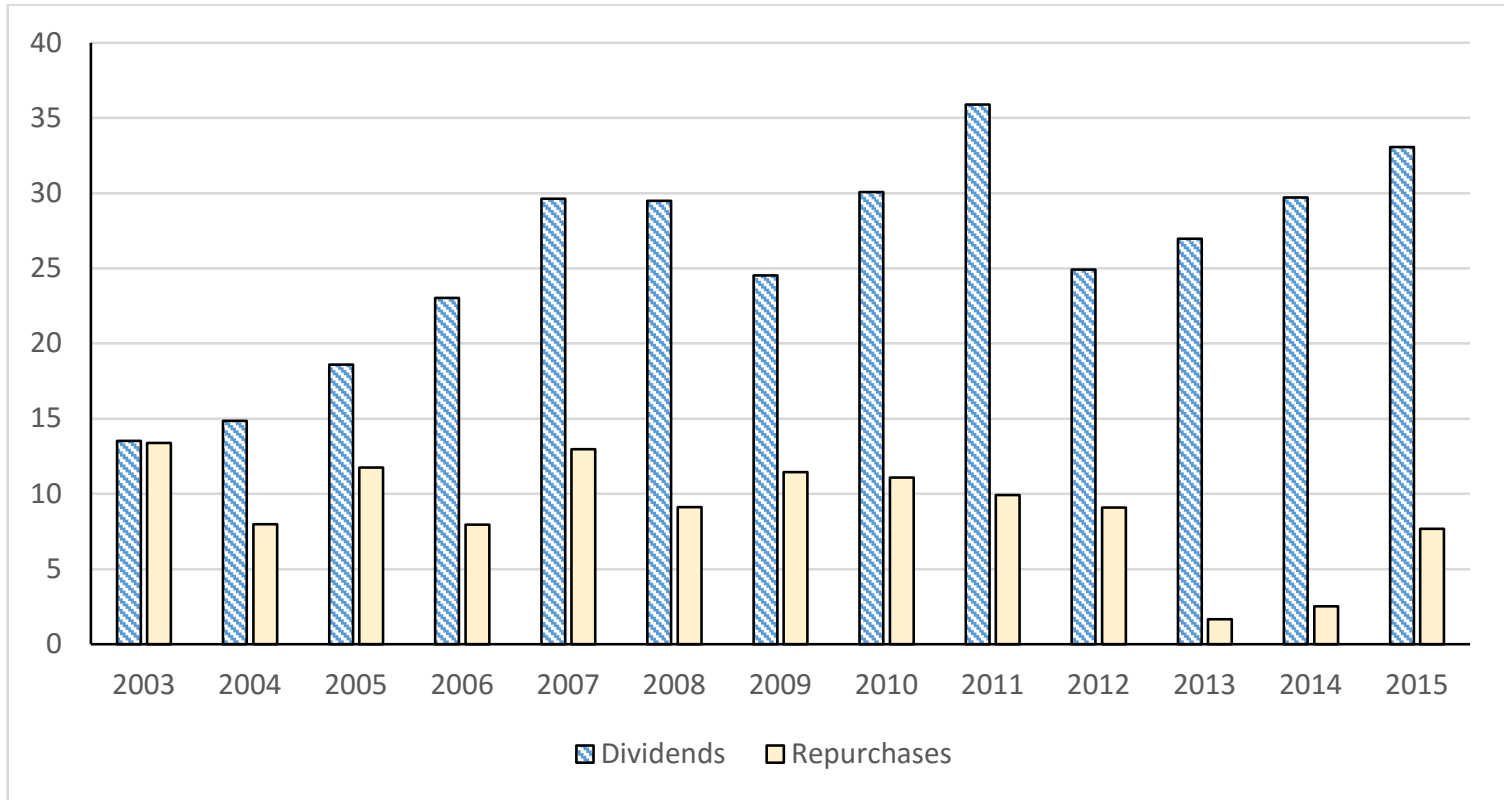

Notes: This panel represents the total amount, in CHF billion, paid in dividends and share repurchases by firms listed on the Swiss stock exchange (SIX) to their shareholders. Source: Swiss National Bank

Panel B: Percentage of firms paying dividends and repurchasing shares

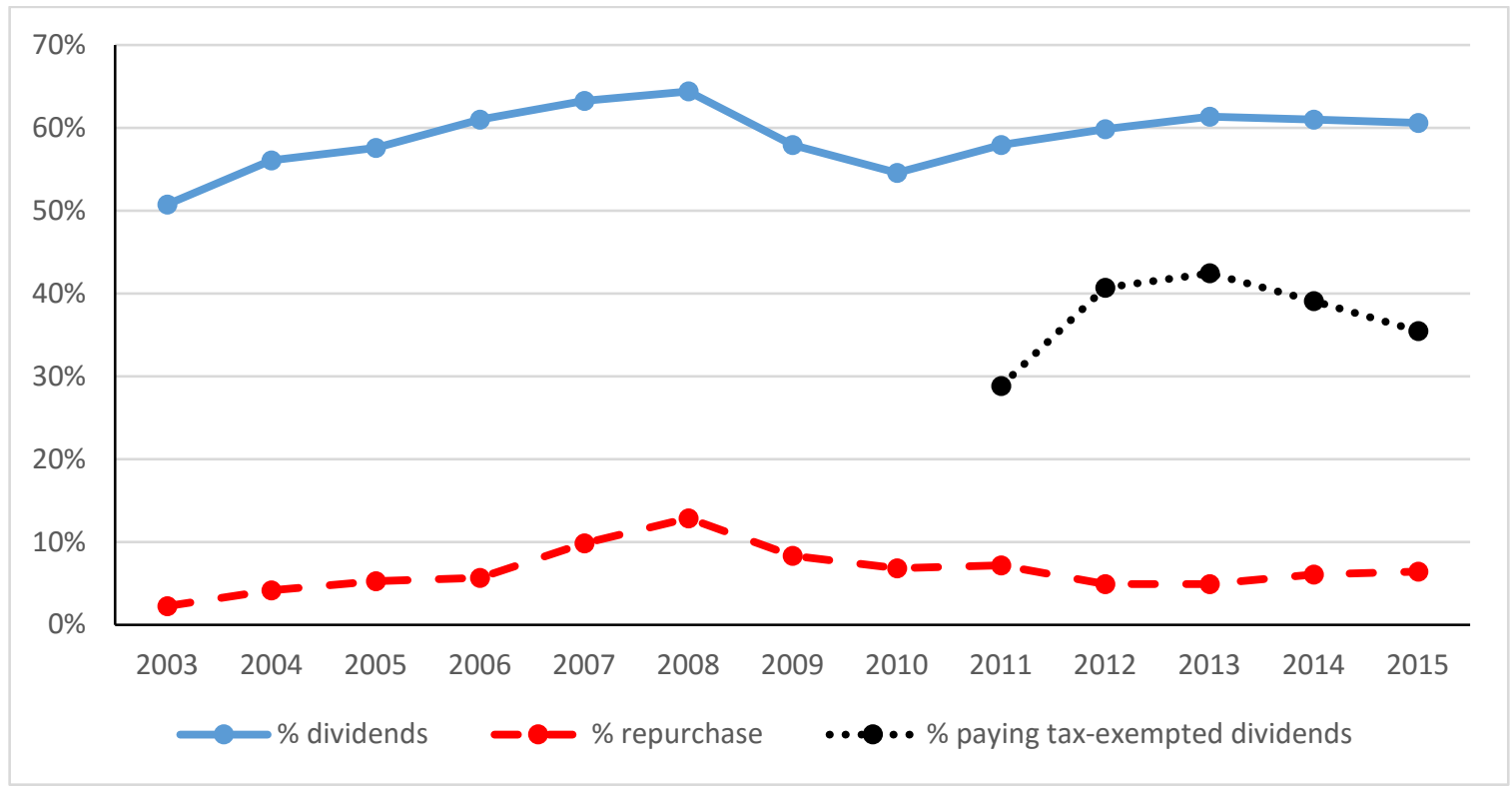

Notes: This panel represents the percentage of firms paying dividends, repurchasing, paying tax-exempted dividends or having a positive payout. 
Figure 2:

Impact of the dividend tax cut on payout
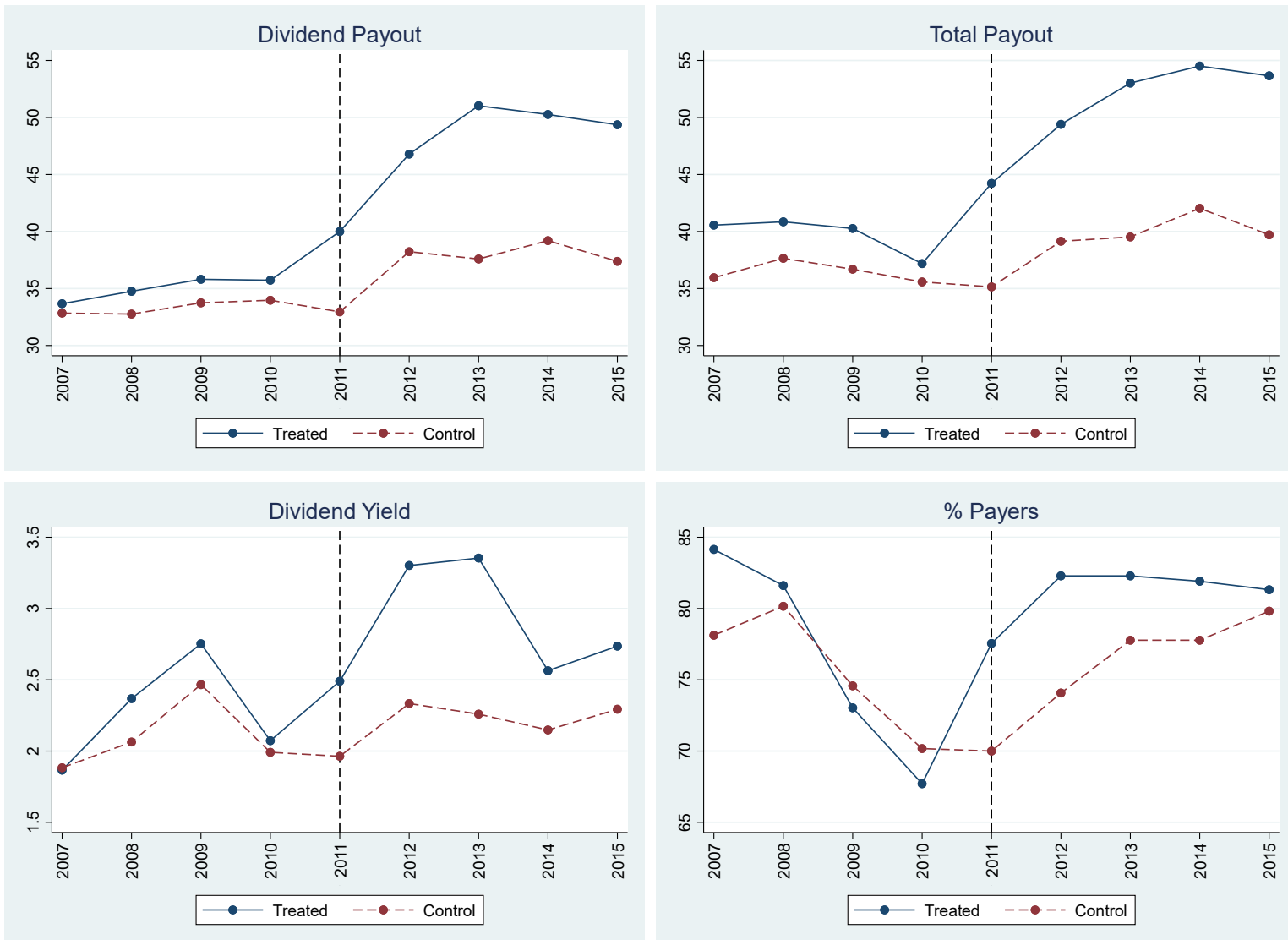

Notes: These figures represent the time series of annual average payout variable for firms in the treatment group (Treated) and in the control group (Control). Firms in the treatment group are firms that had recognized reserves from capital contribution in 2011 and were authorized to pay tax-exempted dividends, while those in the control group did not have such reserves and could not pay tax-exempted dividends. The year 2011 is post-reform. Dividend or total payout is, respectively, the fraction of earnings paid as dividends or as dividends and repurchases cumulated. Dividend yield is the dividend per share divided by the year-end price. Percentage of firms paying dividends is the fraction of firms paying a dividend to their shareholders in the control and treatment groups. 
Figure 3

Impact of the dividend tax cut on corporate investment, equity, and cash
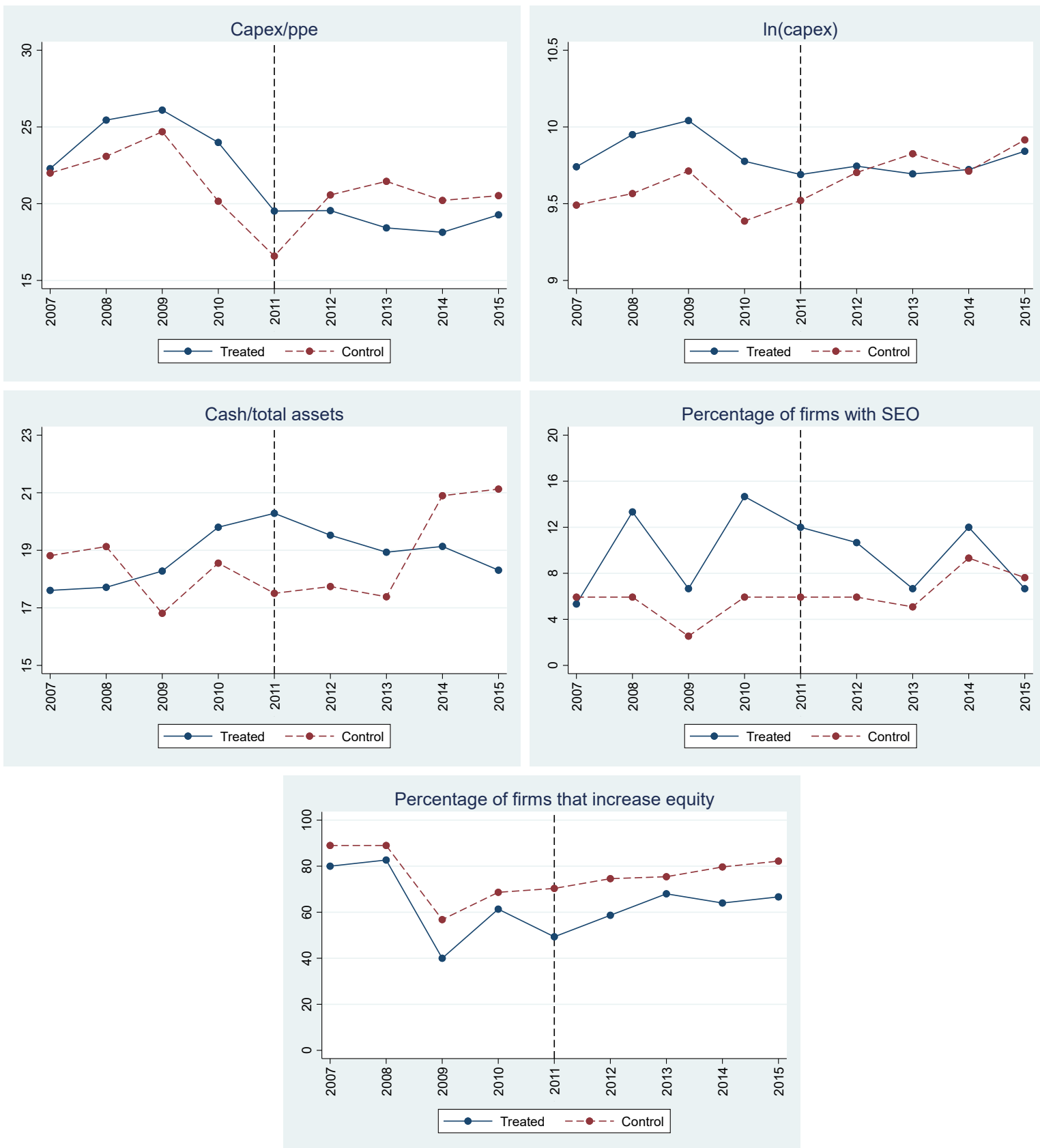

Notes: These figures represent the time series of annual average payout variable for firms in the treatment group (Treated) and in the control group (Control). Firms in the treatment group are firms that had recognized reserves from capital contribution in 2011 and were authorized to pay tax-exempted dividends, while those in the control group did not have such reserve and could not pay tax-exempted dividends. The year 2011 is post-reform. Investments are measured as capex over lagged property, plant \& equipment (PPE). All ratio variables are winsorized at the 1 st and 99th percentiles. 
Figure 4

Impact of the dividend tax cut on payout according to ownership structures
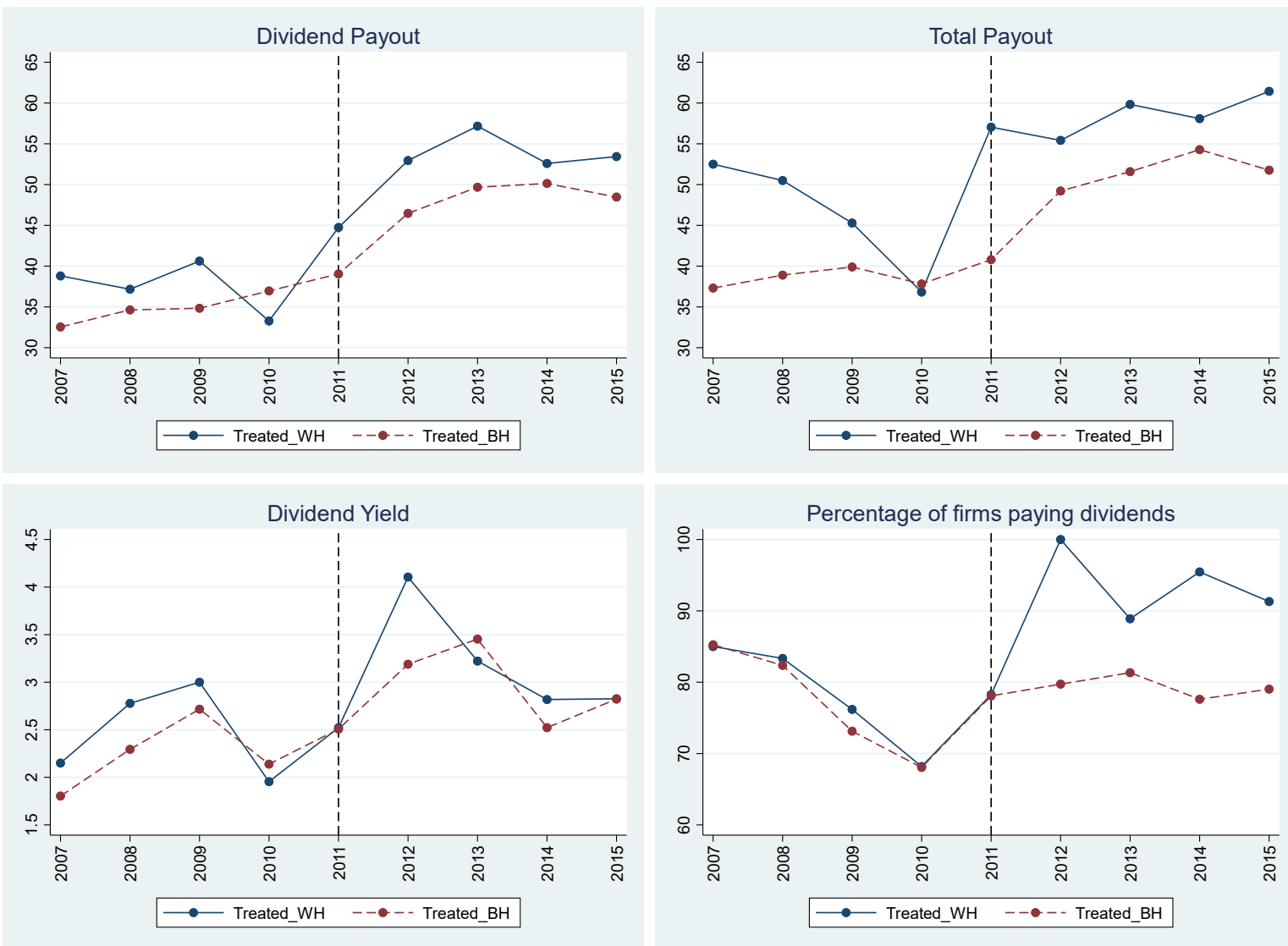

Notes: These figures represent the time series of annual average payout variable for firms in the treatment group. Treated firms are divided into those that are widely-held (Treated $\mathrm{WH})$ and that have one or several blockholders (Treated BH). We define blockholders using a 10\% threshold. The year 2011 is post-reform. Dividend / total payout is the fraction of earnings paid as dividends or as dividends and repurchases cumulated. Dividend yield is the dividend per share divided by the year-end price. Percentage of firms paying dividends is the fraction of firms paying a dividend to their shareholders in the control and treatment groups. 
Table A1

Impact of the tax cut without late arrivals - without financial companies

\begin{tabular}{|c|c|c|c|c|c|c|c|c|}
\hline & \multicolumn{2}{|c|}{ Dividend Yield } & \multicolumn{2}{|c|}{ Dividend Payout } & \multicolumn{2}{|c|}{ Total Payout } & \multicolumn{2}{|c|}{$\%$ Payers } \\
\hline & (1) & (2) & (3) & (4) & $(5)$ & (6) & (7) & $(8)$ \\
\hline Treated & $\begin{array}{c}0.749 * * * \\
(2.931)\end{array}$ & & $\begin{array}{c}8.214^{* *} \\
(2.479)\end{array}$ & & $\begin{array}{c}8.430 * * \\
(2.549)\end{array}$ & & $\begin{array}{c}9.344 * * \\
(2.355)\end{array}$ & \\
\hline Treated (y-1) & & $\begin{array}{c}0.026 \\
(0.115)\end{array}$ & & $\begin{array}{c}1.052 \\
(0.239)\end{array}$ & & $\begin{array}{c}-1.411 \\
(-0.327)\end{array}$ & & $\begin{array}{c}0.104 \\
(0.024)\end{array}$ \\
\hline Treated (y0) & & $\begin{array}{c}0.533 * * \\
(2.252)\end{array}$ & & $\begin{array}{l}7.294 * \\
(1.814)\end{array}$ & & $\begin{array}{c}6.032 \\
(1.396)\end{array}$ & & $\begin{array}{c}10.875^{*} \\
(1.963)\end{array}$ \\
\hline Treated $(y+1)$ & & $\begin{array}{l}0.846^{*} \\
(1.710)\end{array}$ & & $\begin{array}{c}2.977 \\
(0.562)\end{array}$ & & $\begin{array}{c}2.593 \\
(0.410)\end{array}$ & & $\begin{array}{c}4.914 \\
(0.931)\end{array}$ \\
\hline Treated $(\mathrm{y} 2+)$ & & $\begin{array}{c}0.861 * * \\
(2.761)\end{array}$ & & $\begin{array}{c}11.335^{* *} \\
(2.325)\end{array}$ & & $\begin{array}{c}11.397 * * \\
(2.541)\end{array}$ & & $\begin{array}{c}10.123 * \\
(2.004)\end{array}$ \\
\hline Size & $\begin{array}{c}0.076 \\
(1.117)\end{array}$ & $\begin{array}{c}0.082 \\
(1.117)\end{array}$ & $\begin{array}{c}5.560 * * \\
(2.643)\end{array}$ & $\begin{array}{c}5.712 * * \\
(2.761)\end{array}$ & $\begin{array}{c}6.917 * * \\
(2.665)\end{array}$ & $\begin{array}{c}7.110^{* * *} \\
(2.798)\end{array}$ & $\begin{array}{c}3.854 \\
(1.109)\end{array}$ & $\begin{array}{c}3.894 \\
(1.118)\end{array}$ \\
\hline Age & $\begin{array}{c}0.158 \\
(0.255)\end{array}$ & $\begin{array}{c}0.118 \\
(0.187)\end{array}$ & $\begin{array}{c}6.045 \\
(0.825)\end{array}$ & $\begin{array}{c}5.328 \\
(0.743)\end{array}$ & $\begin{array}{c}6.226 \\
(0.681)\end{array}$ & $\begin{array}{c}5.234 \\
(0.580)\end{array}$ & $\begin{array}{c}24.539 * * * \\
(3.012)\end{array}$ & $\begin{array}{c}24.477 * * * \\
\quad(2.896)\end{array}$ \\
\hline Constant & $\begin{array}{c}0.115 \\
(0.048)\end{array}$ & $\begin{array}{c}0.127 \\
(0.051)\end{array}$ & $\begin{array}{l}-60.785 \\
(-1.388)\end{array}$ & $\begin{array}{l}-61.893 \\
(-1.436)\end{array}$ & $\begin{array}{l}-76.222 \\
(-1.331)\end{array}$ & $\begin{array}{l}-76.756 \\
(-1.364)\end{array}$ & $\begin{array}{l}-81.284 \\
(-1.367)\end{array}$ & $\begin{array}{l}-82.044 \\
(-1.376)\end{array}$ \\
\hline Observations & 1,213 & 1,213 & 1,213 & 1,213 & 1,213 & 1,213 & 1,213 & 1,213 \\
\hline R-squared & 0.552 & 0.553 & 0.553 & 0.555 & 0.551 & 0.553 & 0.705 & 0.705 \\
\hline Firm FE & YES & YES & YES & YES & YES & YES & YES & YES \\
\hline Year FE & YES & YES & YES & YES & YES & YES & YES & YES \\
\hline
\end{tabular}

Notes: This table presents results of a difference-in-differences OLS regression over the period 2007-2015 discarding companies which were treated after the shock. We analyse the dividend yield (DPS over stock price), dividend payout (DPS over EPS), total payout (dividends + repurchases over earnings) and the \% of dividend payers. Treated denotes companies exempt from paying dividend taxes. $(y-1)$ denotes the treatment effect one year before the tax cut, $(\mathrm{y} 0)$ the year of the tax cut, $(\mathrm{y}+1)$ the year after the tax cut and $(\mathrm{y} 2+)$ two and more years after the tax cut. Size is the natural logarithm of total assets and Age the natural logarithm of company age. All specifications use industry clustered robust standard errors. *, **, *** denote significance at the $10 \%, 5 \%$ and $1 \%$ level respectively. 
Table A2

Treatment effect on payout over a restricted period and with late arrivals - without financial companies

\begin{tabular}{|c|c|c|c|c|c|c|c|c|}
\hline & \multicolumn{2}{|c|}{ Dividend Yield } & \multicolumn{2}{|c|}{ Dividend Payout } & \multicolumn{2}{|c|}{ Total Payout } & \multicolumn{2}{|c|}{ \% Payers } \\
\hline & (1) & (2) & (3) & (4) & (5) & (6) & (7) & (8) \\
\hline Treated & $\begin{array}{l}0.509 * \\
(2.045)\end{array}$ & & $\begin{array}{l}7.250^{*} \\
(1.885)\end{array}$ & & $\begin{array}{l}6.718 * \\
(1.773)\end{array}$ & & $\begin{array}{c}10.756^{*} \\
(1.918)\end{array}$ & \\
\hline Treated vs. Late & & $\begin{array}{l}0.566^{*} \\
(1.803)\end{array}$ & & $\begin{array}{c}12.522 * * \\
(2.699)\end{array}$ & & $\begin{array}{c}10.064 * * \\
(2.781)\end{array}$ & & $\begin{array}{l}12.995 \\
(1.602)\end{array}$ \\
\hline Size & $\begin{array}{c}0.003 \\
(0.026)\end{array}$ & $\begin{array}{c}-0.049 \\
(-0.369)\end{array}$ & $\begin{array}{c}2.974 \\
(1.067)\end{array}$ & $\begin{array}{c}2.807 \\
(0.882)\end{array}$ & $\begin{array}{c}5.467 \\
(1.579)\end{array}$ & $\begin{array}{c}6.206 \\
(1.593)\end{array}$ & $\begin{array}{c}3.988 \\
(0.976)\end{array}$ & $\begin{array}{c}2.726 \\
(0.545)\end{array}$ \\
\hline Age & $\begin{array}{c}0.409 \\
(0.368)\end{array}$ & $\begin{array}{c}1.122 \\
(0.981)\end{array}$ & $\begin{array}{l}-11.828 \\
(-0.544)\end{array}$ & $\begin{array}{c}1.131 \\
(0.050)\end{array}$ & $\begin{array}{l}-16.726 \\
(-0.680)\end{array}$ & $\begin{array}{c}-7.213 \\
(-0.270)\end{array}$ & $\begin{array}{l}21.231 \\
(0.870)\end{array}$ & $\begin{array}{c}39.104 * * \\
(2.295)\end{array}$ \\
\hline Constant & $\begin{array}{c}-0.022 \\
(-0.005)\end{array}$ & $\begin{array}{c}-2.243 \\
(-0.463)\end{array}$ & $\begin{array}{l}35.418 \\
(0.401)\end{array}$ & $\begin{array}{l}-20.670 \\
(-0.208)\end{array}$ & $\begin{array}{l}25.415 \\
(0.261)\end{array}$ & $\begin{array}{l}-28.051 \\
(-0.261)\end{array}$ & $\begin{array}{l}-73.937 \\
(-0.690)\end{array}$ & $\begin{array}{c}-129.727 \\
(-1.289)\end{array}$ \\
\hline Observations & 765 & 513 & 765 & 513 & 765 & 513 & 765 & 513 \\
\hline R-squared & 0.649 & 0.640 & 0.585 & 0.584 & 0.576 & 0.571 & 0.764 & 0.733 \\
\hline Firm FE & YES & YES & YES & YES & YES & YES & YES & YES \\
\hline Year FE & YES & YES & YES & YES & YES & YES & YES & YES \\
\hline
\end{tabular}

This table presents results of a difference-in differences OLS regression over the period 2007-2015 comparing the treatment effect over a shorter period between 2007 and 2011 (columns 1, 3 and 5) and treated firms to late treated firms only (columns 2, 4 and 6). We analyse the dividend yield (DPS over stock price), dividend payout (DPS over EPS), total payout (dividends + repurchases over earnings) and the $\%$ of dividend payers. Size is the natural logarithm of total assets and Age the natural logarithm of company age. All specifications use industry clustered robust standard errors. * $* *, * * *$ denote significance at the $10 \%, 5 \%$ and $1 \%$ level respectively. 
Table A3

Treatment effect on payout - without largest or smallest companies

\begin{tabular}{|c|c|c|c|c|c|c|c|c|}
\hline \multicolumn{9}{|c|}{ Panel A: sample without top quintile companies } \\
\hline & \multicolumn{2}{|c|}{ Dividend Yield } & \multicolumn{2}{|c|}{ Dividend Payout } & \multicolumn{2}{|c|}{ Total Payout } & \multicolumn{2}{|c|}{$\%$ Payers } \\
\hline & (1) & (2) & (3) & (4) & $(5)$ & $(6)$ & (7) & (8) \\
\hline Treated & $\begin{array}{c}0.723 * * * \\
(3.314)\end{array}$ & & $\begin{array}{c}9.156 * * * \\
(4.014)\end{array}$ & & $\begin{array}{c}8.689 * * * \\
(3.309)\end{array}$ & & $\begin{array}{c}6.742 * * \\
(2.081)\end{array}$ & \\
\hline Treated $(y-1)$ & & $\begin{array}{c}-0.003 \\
(-0.016)\end{array}$ & & $\begin{array}{c}0.334 \\
(0.090)\end{array}$ & & $\begin{array}{c}-2.085 \\
(-0.585)\end{array}$ & & $\begin{array}{c}-3.273 \\
(-0.734)\end{array}$ \\
\hline Treated (y0) & & $\begin{array}{c}0.602 * * \\
(2.610)\end{array}$ & & $\begin{array}{l}7.710 * \\
(1.982)\end{array}$ & & $\begin{array}{c}6.514 \\
(1.601)\end{array}$ & & $\begin{array}{l}9.438 * \\
(1.865)\end{array}$ \\
\hline Treated $(y+1)$ & & $\begin{array}{l}0.946^{*} \\
(1.908)\end{array}$ & & $\begin{array}{c}6.285 \\
(1.454)\end{array}$ & & $\begin{array}{c}4.816 \\
(0.953)\end{array}$ & & $\begin{array}{c}6.751 \\
(1.331)\end{array}$ \\
\hline Treated $(\mathrm{y} 2+)$ & & $\begin{array}{c}0.689 * * * \\
(3.036)\end{array}$ & & $\begin{array}{c}10.940 * * * \\
(3.532)\end{array}$ & & $\begin{array}{c}9.979 * * * \\
(3.182)\end{array}$ & & $\begin{array}{c}4.104 \\
(1.046)\end{array}$ \\
\hline Size & $\begin{array}{c}-0.073 \\
(-0.461)\end{array}$ & $\begin{array}{c}-0.074 \\
(-0.453)\end{array}$ & $\begin{array}{c}2.817 \\
(1.027)\end{array}$ & $\begin{array}{c}2.897 \\
(1.053)\end{array}$ & $\begin{array}{c}3.267 \\
(1.058)\end{array}$ & $\begin{array}{c}3.370 \\
(1.088)\end{array}$ & $\begin{array}{c}1.058 \\
(0.285)\end{array}$ & $\begin{array}{c}0.981 \\
(0.262)\end{array}$ \\
\hline Age & $\begin{array}{c}0.180 \\
(0.321)\end{array}$ & $\begin{array}{c}0.180 \\
(0.318)\end{array}$ & $\begin{array}{c}2.202 \\
(0.317)\end{array}$ & $\begin{array}{c}1.925 \\
(0.277)\end{array}$ & $\begin{array}{c}2.565 \\
(0.311)\end{array}$ & $\begin{array}{c}2.221 \\
(0.271)\end{array}$ & $\begin{array}{l}17.026 \\
(1.210)\end{array}$ & $\begin{array}{c}17.337 \\
(1.224)\end{array}$ \\
\hline Constant & $\begin{array}{c}2.011 \\
(0.865)\end{array}$ & $\begin{array}{c}2.020 \\
(0.866)\end{array}$ & $\begin{array}{l}-14.137 \\
(-0.317)\end{array}$ & $\begin{array}{l}-14.137 \\
(-0.319)\end{array}$ & $\begin{array}{l}-16.719 \\
(-0.315)\end{array}$ & $\begin{array}{l}-16.732 \\
(-0.318)\end{array}$ & $\begin{array}{c}-0.956 \\
(-0.013)\end{array}$ & $\begin{array}{c}-1.094 \\
(-0.014)\end{array}$ \\
\hline Observations & 1,488 & 1,488 & 1,488 & 1,488 & 1,488 & 1,488 & 1,488 & 1,488 \\
\hline R-squared & 0.604 & 0.604 & 0.580 & 0.581 & 0.573 & 0.574 & 0.677 & 0.677 \\
\hline Firm FE & YES & YES & YES & YES & YES & YES & YES & YES \\
\hline Year FE & YES & YES & YES & YES & YES & YES & YES & YES \\
\hline \multicolumn{9}{|c|}{ Panel B: sample without bottom quintile companies } \\
\hline & \multicolumn{2}{|c|}{ Dividend Yield } & \multicolumn{2}{|c|}{ Dividend Payout } & \multicolumn{2}{|c|}{ Total Payout } & \multicolumn{2}{|c|}{$\%$ Payers } \\
\hline & $(1)$ & $(2)$ & (3) & $(4)$ & $(5)$ & $(6)$ & $(7)$ & $(8)$ \\
\hline Treated & $\begin{array}{c}0.614 * * \\
(2.369)\end{array}$ & & $\begin{array}{c}8.256^{* * *} \\
(3.758)\end{array}$ & & $\begin{array}{c}9.414 * * * \\
(3.595)\end{array}$ & & $\begin{array}{c}6.463 * * \\
(2.262)\end{array}$ & \\
\hline Treated $(y-1)$ & & $\begin{array}{c}0.063 \\
(0.331)\end{array}$ & & $\begin{array}{c}-0.407 \\
(-0.099)\end{array}$ & & $\begin{array}{c}-2.276 \\
(-0.624)\end{array}$ & & $\begin{array}{c}-2.405 \\
(-0.601)\end{array}$ \\
\hline Treated $(\mathrm{y} 0)$ & & $\begin{array}{c}0.396 \\
(1.658)\end{array}$ & & $\begin{array}{c}6.544 \\
(1.632)\end{array}$ & & $\begin{array}{l}7.077 * \\
(1.832)\end{array}$ & & $\begin{array}{c}7.638 \\
(1.641)\end{array}$ \\
\hline Treated $(y+1)$ & & $\begin{array}{l}0.779 * \\
(2.030)\end{array}$ & & $\begin{array}{c}6.415 \\
(1.548)\end{array}$ & & $\begin{array}{c}7.240 \\
(1.396)\end{array}$ & & $\begin{array}{c}8.837 * * \\
(2.261)\end{array}$ \\
\hline Treated $(\mathrm{y} 2+)$ & & $\begin{array}{l}0.666^{*} \\
(1.958)\end{array}$ & & $\begin{array}{c}9.375 * * * \\
(3.336)\end{array}$ & & $\begin{array}{c}10.029 * * * \\
(3.364)\end{array}$ & & $\begin{array}{c}4.066 \\
(1.100)\end{array}$ \\
\hline Size & $\begin{array}{c}-0.487 * * \\
(-2.130)\end{array}$ & $\begin{array}{c}-0.481 * * \\
(-2.068)\end{array}$ & $\begin{array}{c}-3.339 \\
(-0.891)\end{array}$ & $\begin{array}{c}-3.265 \\
(-0.881)\end{array}$ & $\begin{array}{c}-2.388 \\
(-0.471)\end{array}$ & $\begin{array}{c}-2.326 \\
(-0.459)\end{array}$ & $\begin{array}{c}-10.433^{*} \\
(-1.888)\end{array}$ & $\begin{array}{r}-10.556^{*} \\
(-1.904)\end{array}$ \\
\hline Age & $\begin{array}{c}0.547 \\
(0.855)\end{array}$ & $\begin{array}{c}0.530 \\
(0.818)\end{array}$ & $\begin{array}{c}5.380 \\
(0.567)\end{array}$ & $\begin{array}{c}5.147 \\
(0.545)\end{array}$ & $\begin{array}{c}4.292 \\
(0.446)\end{array}$ & $\begin{array}{c}4.028 \\
(0.421)\end{array}$ & $\begin{array}{l}20.011 \\
(1.125)\end{array}$ & $\begin{array}{l}20.279 \\
(1.140)\end{array}$ \\
\hline Constant & $\begin{array}{l}6.910 * \\
(2.028)\end{array}$ & $\begin{array}{l}6.891^{*} \\
(2.002)\end{array}$ & $\begin{array}{l}62.487 \\
(1.095)\end{array}$ & $\begin{array}{l}62.321 \\
(1.103)\end{array}$ & $\begin{array}{l}58.944 \\
(0.752)\end{array}$ & $\begin{array}{l}59.096 \\
(0.758)\end{array}$ & $\begin{array}{c}161.416^{*} \\
(1.944)\end{array}$ & $\begin{array}{r}162.156^{*} \\
(1.945)\end{array}$ \\
\hline Observations & 1,488 & 1,488 & 1,488 & 1,488 & 1,488 & 1,488 & 1,488 & 1,488 \\
\hline R-squared & 0.598 & 0.599 & 0.516 & 0.516 & 0.495 & 0.496 & 0.574 & 0.575 \\
\hline Firm FE & YES & YES & YES & YES & YES & YES & YES & YES \\
\hline Year FE & YES & YES & YES & YES & YES & YES & YES & YES \\
\hline
\end{tabular}

This table presents results of a difference-in-differences OLS regression over the period 2006-2014. We analyse the dividend yield (DPS over stock price), dividend payout (DPS over EPS), total payout (dividends + repurchases over earnings) and the \% of dividend payers. Treated denotes companies exempt from paying dividend taxes. ( $\mathrm{y}-$ 1) denotes the treatment effect one year before the tax cut, (y0) the year of the tax cut, $(y+1)$ the year after the tax cut and $(\mathrm{y} 2+)$ two and more years after the tax cut. Size is the natural logarithm of total assets and age the natural logarithm of company age. Panel A (B) reports results for a sample without the top (bottom) quintile companies in terms of total assets. All specifications use industry clustered robust standard errors. *, **, *** denote significance at the $10 \%, 5 \%$ and $1 \%$ level respectively. 
Table A4

Treatment effect on corporate investment - alternative winsorizing thresholds

\begin{tabular}{|c|c|c|c|c|c|c|c|c|}
\hline & & & & & PPE & & & \\
\hline & (1) & (2) & (3) & (4) & $(5)$ & $(6)$ & (7) & (8) \\
\hline Treated & $\begin{array}{c}1.961 \\
(0.606)\end{array}$ & & & & $\begin{array}{c}0.953 \\
(0.455)\end{array}$ & & & \\
\hline Treated w/out late & & $\begin{array}{c}3.006 \\
(0.983)\end{array}$ & & & & $\begin{array}{c}1.192 \\
(0.559)\end{array}$ & & \\
\hline Treated & & & $\begin{array}{c}6.374 \\
(1.275)\end{array}$ & & & & $\begin{array}{c}2.425 \\
(0.719)\end{array}$ & \\
\hline Treated vs. Late & & & & $\begin{array}{c}6.258 \\
(1.350)\end{array}$ & & & & $\begin{array}{c}3.232 \\
(1.070)\end{array}$ \\
\hline Size & $\begin{array}{c}-3.911 \\
(-1.201)\end{array}$ & $\begin{array}{c}0.028 \\
(0.012)\end{array}$ & $\begin{array}{c}-7.659 * * \\
(-2.442)\end{array}$ & $\begin{array}{c}-4.627 \\
(-0.995)\end{array}$ & $\begin{array}{c}-2.882 \\
(-1.371)\end{array}$ & $\begin{array}{c}-0.577 \\
(-0.330)\end{array}$ & $\begin{array}{c}-6.558 * * * \\
(-3.240)\end{array}$ & $\begin{array}{c}-4.055 \\
(-1.084)\end{array}$ \\
\hline Age & $\begin{array}{l}-6.229 \\
(-1.642)\end{array}$ & $\begin{array}{c}-12.439 * \\
(-1.944)\end{array}$ & $\begin{array}{c}-4.263 \\
(-0.572)\end{array}$ & $\begin{array}{c}-5.647 \\
(-0.781)\end{array}$ & $\begin{array}{c}-5.480 \\
(-1.379)\end{array}$ & $\begin{array}{c}-10.202 * \\
(-1.784)\end{array}$ & $\begin{array}{c}-5.380 \\
(-1.103)\end{array}$ & $\begin{array}{l}-6.056 \\
(-1.264)\end{array}$ \\
\hline Constant & $\begin{array}{c}104.479 * * \\
(2.159)\end{array}$ & $\begin{array}{c}75.513^{*} \\
(1.871)\end{array}$ & $\begin{array}{c}143.596 * * \\
(2.349)\end{array}$ & $\begin{array}{c}106.755 \\
(1.453)\end{array}$ & $\begin{array}{c}85.980 * * \\
(2.482)\end{array}$ & $\begin{array}{c}74.399 * * \\
(2.562)\end{array}$ & $\begin{array}{c}131.931 * * * \\
(4.238)\end{array}$ & $\begin{array}{r}99.449 * \\
(1.956)\end{array}$ \\
\hline Observations & 1,362 & 1,238 & 516 & 773 & 1,362 & 1,238 & 516 & 773 \\
\hline R-squared & 0.734 & 0.749 & 0.840 & 0.808 & 0.692 & 0.707 & 0.807 & 0.770 \\
\hline Firm FE & YES & YES & YES & YES & YES & YES & YES & YES \\
\hline Year FE & YES & YES & YES & YES & YES & YES & YES & YES \\
\hline
\end{tabular}

This table presents results of a difference-in-differences OLS regression over the period 2007-2015 comparing treated firms to control firms (columns 1 and 5), treated firms to a control group discarding late arrivals (columns 2 and 6), the treatment effect over a shorter period between 2007 and 2011 (columns 3 and 7) and treated firms to late treated firms only (columns 4 and 8). The explained variable is the ratio of capex over lagged PPE winsorized at the 2.5 and 97.5 percentiles (columns 1 to 4 ) and at the 5 and 95 percentiles (columns 5 to 8 ). Size is the natural logarithm of total assets and Age the natural logarithm of company age. All specifications use industry clustered robust standard errors. $* * *, * * *$ denote significance at the $10 \%, 5 \%$ and $1 \%$ level respectively. 
Table A5

Treatment effect on financing options - alternative winsorizing thresholds

\begin{tabular}{|c|c|c|c|c|c|c|c|c|}
\hline \multicolumn{9}{|c|}{ Panel A: Treatment on book value of equity } \\
\hline \multicolumn{9}{|c|}{ BV equity / total as sets } \\
\hline & $(1)$ & (2) & (3) & (4) & $(5)$ & $(6)$ & $(7)$ & $(8)$ \\
\hline Treated & $\begin{array}{c}2.581 \\
(1.115)\end{array}$ & & & & $\begin{array}{c}2.515 \\
(1.111)\end{array}$ & & & \\
\hline Treated w/out late & & $\begin{array}{c}2.564 \\
(1.109)\end{array}$ & & & & $\begin{array}{c}2.664 \\
(1.177)\end{array}$ & & \\
\hline Treated & & & $\begin{array}{c}2.258 \\
(0.828)\end{array}$ & & & & $\begin{array}{c}2.379 \\
(0.893)\end{array}$ & \\
\hline Treated vs. Late & & & & $\begin{array}{c}2.713 \\
(0.924)\end{array}$ & & & & $\begin{array}{c}2.686 \\
(0.947)\end{array}$ \\
\hline Size & $\begin{array}{c}4.896 * * \\
(2.540)\end{array}$ & $\begin{array}{c}4.868 * * \\
(2.324)\end{array}$ & $\begin{array}{c}2.479 \\
(0.795)\end{array}$ & $\begin{array}{c}0.706 \\
(0.290)\end{array}$ & $\begin{array}{c}4.676^{* *} \\
(2.486)\end{array}$ & $\begin{array}{c}4.610 * * \\
(2.235)\end{array}$ & $\begin{array}{c}2.604 \\
(0.851)\end{array}$ & $\begin{array}{c}0.780 \\
(0.322)\end{array}$ \\
\hline Age & $\begin{array}{c}-3.779 \\
(-0.928)\end{array}$ & $\begin{array}{c}-3.877 \\
(-0.844)\end{array}$ & $\begin{array}{c}-0.870 \\
(-0.151)\end{array}$ & $\begin{array}{c}3.791 \\
(0.701)\end{array}$ & $\begin{array}{c}-2.952 \\
(-0.825)\end{array}$ & $\begin{array}{c}-3.346 \\
(-0.797)\end{array}$ & $\begin{array}{c}-0.577 \\
(-0.106)\end{array}$ & $\begin{array}{c}4.111 \\
(0.788)\end{array}$ \\
\hline Constant & $\begin{array}{c}0.099 \\
(0.004)\end{array}$ & $\begin{array}{c}0.825 \\
(0.028)\end{array}$ & $\begin{array}{l}22.876 \\
(0.675)\end{array}$ & $\begin{array}{l}26.481 \\
(0.870)\end{array}$ & $\begin{array}{c}-0.422 \\
(-0.016)\end{array}$ & $\begin{array}{c}1.861 \\
(0.064)\end{array}$ & $\begin{array}{l}19.693 \\
(0.593)\end{array}$ & $\begin{array}{l}23.989 \\
(0.776)\end{array}$ \\
\hline Observations & 1,408 & 1,285 & 814 & 536 & 1,408 & 1,285 & 814 & 536 \\
\hline R-squared & 0.780 & 0.783 & 0.834 & 0.861 & 0.780 & 0.783 & 0.833 & 0.856 \\
\hline Firm FE & YES & YES & YES & YES & YES & YES & YES & YES \\
\hline Year FE & YES & YES & YES & YES & YES & YES & YES & YES \\
\hline \multicolumn{9}{|c|}{ Panel B: Treatment on cash \& equivalents } \\
\hline & & & Cash \& e & / total asse & & & & \\
\hline & $(1)$ & $(2)$ & (3) & (4) & $(5)$ & $(6)$ & $(7)$ & $(8)$ \\
\hline Treated & $\begin{array}{c}0.408 \\
(0.341)\end{array}$ & & & & $\begin{array}{c}0.464 \\
(0.409)\end{array}$ & & & \\
\hline Treated w/out late & & $\begin{array}{c}0.614 \\
(0.487)\end{array}$ & & & & $\begin{array}{c}0.581 \\
(0.481)\end{array}$ & & \\
\hline Treated & & & $\begin{array}{c}1.533 \\
(0.839)\end{array}$ & & & & $\begin{array}{c}1.417 \\
(0.855)\end{array}$ & \\
\hline Treated vs. Late & & & & $\begin{array}{c}-0.419 \\
(-0.193)\end{array}$ & & & & $\begin{array}{c}-0.291 \\
(-0.150)\end{array}$ \\
\hline Size & $\begin{array}{c}-1.291 \\
(-0.844)\end{array}$ & $\begin{array}{c}-0.513 \\
(-0.359)\end{array}$ & $\begin{array}{c}-0.562 \\
(-0.182)\end{array}$ & $\begin{array}{c}-3.829 * * * \\
(-5.251)\end{array}$ & $\begin{array}{c}-1.327 \\
(-1.003)\end{array}$ & $\begin{array}{c}-0.861 \\
(-0.669)\end{array}$ & $\begin{array}{c}-0.544 \\
(-0.201)\end{array}$ & $\begin{array}{c}-3.322 * * * \\
(-4.639)\end{array}$ \\
\hline Age & $\begin{array}{c}-2.230 \\
(-0.758)\end{array}$ & $\begin{array}{c}-2.687 \\
(-0.871)\end{array}$ & $\begin{array}{c}-0.420 \\
(-0.101)\end{array}$ & $\begin{array}{c}0.803 \\
(0.185)\end{array}$ & $\begin{array}{c}-1.225 \\
(-0.526)\end{array}$ & $\begin{array}{c}-1.479 \\
(-0.662)\end{array}$ & $\begin{array}{c}0.575 \\
(0.152)\end{array}$ & $\begin{array}{c}1.882 \\
(0.472)\end{array}$ \\
\hline Constant & $\begin{array}{c}44.851^{*} \\
(1.819)\end{array}$ & $\begin{array}{l}36.144 \\
(1.629)\end{array}$ & $\begin{array}{l}27.155 \\
(0.718)\end{array}$ & $\begin{array}{c}68.070 * * * \\
\quad(5.971)\end{array}$ & $\begin{array}{c}40.731 * \\
(1.908)\end{array}$ & $\begin{array}{r}35.528 * \\
(1.812)\end{array}$ & $\begin{array}{l}22.460 \\
(0.673)\end{array}$ & $\begin{array}{c}56.388 * * * \\
\quad(4.550)\end{array}$ \\
\hline Observations & 1,406 & 1,283 & 812 & 536 & 1,406 & 1,283 & 812 & 536 \\
\hline R-squared & 0.769 & 0.769 & 0.822 & 0.852 & 0.753 & 0.753 & 0.813 & 0.839 \\
\hline Firm FE & YES & YES & YES & YES & YES & YES & YES & YES \\
\hline Year FE & YES & YES & YES & YES & YES & YES & YES & YES \\
\hline
\end{tabular}

This table presents results of a difference-in-differences OLS regression over the period 2007-2015 comparing treated firms to control firms (columns 1 and 5), treated firms to a control group discarding late arrivals (columns 2 and 6), the treatment effect over a shorter period between 2007 and 2011 (columns 3 and 7) and treated firms to late treated firms only (columns 4 and 8). The explained variable is the ratio of book value of equity over total assets (Panel A) and cash \& equivalents over total assets (Panel B). The variables are winsorized at the 2.5-97.5\% level in columns 1 to 4 , and at the 5-95\% level in columns 5 to 8 . Size is the natural logarithm of total assets and Age the natural logarithm of company age. All specifications use industry clustered robust standard errors. *, **, $* * *$ denote significance at the $10 \%, 5 \%$ and $1 \%$ level respectively. 


\title{
Authors
}

Dušan ISAKOV

University of Fribourg, Boulevard de Pérolles 90, CH-1700 Fribourg, Switzerland

email: dusan.isakov@unifr.ch More on http://www.unifr.ch/cgf

Christophe PÉRIGNON

HEC Paris, 1 Rue de la Libération, 78350 Jouy-en-Josas, France

email: perignon@hec.fr More on https://people.hec.edu/perignon

Jean-Philippe WEISSKOPF

Ecole hôtelière de Lausanne, HES-SO / University of Applied Sciences Western Switzerland, Route de Cojonnex 18, CH-1000

Lausanne, Switzerland. email: jean-philippe.weisskopf@ehl.ch More on https://www.ehl.edu/en/dr-weisskopf-jean-philippe

\begin{abstract}
We study the effect of dividend taxes on the payout and investment policy of listed firms and discuss their implications for agency problems. To do so, we exploit a unique setting in Switzerland where some, but not all, firms were suddenly able to pay tax-exempted dividends to their shareholders following the corporate tax reform of 2011. Using a difference-in-differences specification, we show that treated firms increased their payout much more than control firms after the tax cut. Differently, treated firms did not concurrently or subsequently increase investment. We show that the tax-inelasticity of investment was due to a significant drop in retained earnings - as the rise in dividends was not compensated by an equally-sized reduction in share repurchases. Furthermore, treated firms did not raise more equity and/or did not reduce their cash holdings to compensate for the contraction in retained earnings. Finally, we show that an unintended consequence of cutting dividend taxes is to mitigate the agency problems that arise between insiders and minority shareholders.
\end{abstract}

\section{Citation proposal}

Dušan Isakov, Christophe Pérignon, Jean-Philippe Weisskopf. 2018. «What if dividends were tax-exempt? Evidence from a natural experiment». Working Papers SES 498, Faculty of Economics and Social Sciences, University of Fribourg (Switzerland)

\section{Jel Classification}

G35, G38, H25, K34.

\section{Keywords}

Corporate taxes, dividends, payouts, investment, agency problems.

\section{Working Papers SES collection}

\section{Last published}

491 Eugster N.: Family Firms and Financial Analyst Activity; 2017

492 Andresen M.E., Huber M.: Instrument-based estimation with binarized treatments: Issues and tests for the exclusion restriction; 2018

493 Bodory H., Huber M.: The causalweight package for causal inference in R; 2018

494 Huber M., Imhof D.: Machine Learning with Screens for Detecting Bid-Rigging Cartels; 2018

495 Hsu Y.-C., Huber M., Lee Y.-Y.: Direct and indirect effects of continuous treatments based on generalized propensity score weighting; 2018

496 Huber M., Solovyeva A.: Direct and indirect effects under sample selection and outcome attrition; 2018

497 Huber M., Solovyeva A.: On the sensitivity of wage gap decompositions; 2018

\section{Catalogue and download links}

http://www.unifr.ch/ses/wp

http://doc.rero.ch/collection/WORKING_PAPERS_SES

\section{Publisher}

Université de Fribourg, Suisse, Faculté des sciences économiques et sociales Universität Freiburg, Schweiz, Wirtschafts- und sozialwissenschaftliche Fakultät University of Fribourg, Switzerland, Faculty of Economics and Social Sciences
Bd de Pérolles 90, $\mathrm{CH}-1700$ Fribourg

Tél.: +41 (0) 263008200

decanat-ses@unifr.ch www.unifr.ch/ses 